\title{
Új módszer a fosszilis csontok korának meghatározására az aminosavak racemizációja alapján
}

\begin{abstract}
'CSAPÓ JÁNOS
'Debreceni Egyetem, Mezőgazdaság-, Élelmiszertudományi és Környezetgazdálkodási Kar, Élelmiszertechnológiai Intézet, H-4032 Debrecen, Böszörményi u. 138., e-mail: csapo.janos@gmail.hu

'SAPIENTIA Erdélyi Magyar Tudományegyetem, Csíkszeredai Kar, Élelmiszertudományi Tanszék, RO-4100 Csíkszereda, Szabadság tér 1., e-mail: csapo.janos@gmail.hu

CSAPÓ, J.: New method for the age determination of fossilized bones based on amino acid racemization

Abstract: After developing protein hydrolysis method with low racemization, a method has been developed to determine the age of fossil bone samples based on amino acid racemization (AAR). Approximately one hundred fossil bone samples of known age from Hungary were collected and analysed for D- and L- amino acids. As the racemization of amino acids is affected by temperature, $\mathrm{pH}$, metal content of the soil, and time passed since death, these factors were eliminated by comparing the estimated age to age determined by the radiocarbon method. Determining the $D$ - and L- amino acid contents in samples of known age, determining the half life of racemization, and plotting the $D / L$ ratio as a function of time, calibration curves were obtained. These curves can be used for the age estimation of samples after determining their D- and L- amino acid content. The D/L ratio for 2 to 3 amino acids was determined for each sample and the mean value of estimated ages based on calibration curves was considered to estimate age of the fossil samples.
\end{abstract}

Keywords: fossil bones, amino acids, racemization, epimerization, age determination

\section{Előszó}

Dr. Költő Lászlóval 1985-ben ismerkedtem meg, amikor egy tudósklubi összejövetelen elmondtam neki, hogy az akkori munkahelyemen többek között a fehérje aminosav összetételének meghatározásával is foglalkozom. Ő megkérdezte tőlem, hogy esetleg fosszilis csontokból nem tudnék-e aminosavakat meghatározni, mert az eredményeket jól tudnánk használni a csontok korának meghatározására. Közben kiderült, hogy valójában a D- és L-aminosavakat kellene egymástól szétválasztani és egymás mellett meghatározni, ami egy sokkal bonyolultabb probléma volt, mint egy "egyszerü" aminosav analízis. A korabeli technikával ez nem volt könnyü, de megoldottuk. Volt sok feladat, de végül is kb. öt év alatt eljutottunk oda, hogy képesek voltunk rutinszerủen analizálni a csontokat. Közben módszert dolgoztunk ki gyapjúszőnyegek korának meghatározására az aminosavak bomlása és oxidációja alapján, a halál idejének becslésére a fogak, D-aminosav tartalmának analízisével, és korrigáltuk az előttünk alkalmazott módszerek kisebb-nagyobb hibáit. Summa summarum, ha nem találkozom Költő Lászlóval, ezek a módszerek nem születtek volna meg, nem tudtunk volna előadásokat tartani archeológia világkonferenciákon, és az impakt faktorom is jóval kevesebb lenne. Köszönet érte Lacinak.

\section{Bevezetés}

A pontos kormeghatározás rendkívül fontos a régész számára, mert egyrészt lehetővé teszi a vizsgált időszak objektív meghatározását, mely egy adott környezetben bizonyos kulturális vagy technológiai szint eléréséhez szükséges, másrészt a pontos kormeghatározás nélkülözhetetlen ahhoz, hogy megértsük miként terjedtek szét az ismeretek a Földön, vagy kijelenthessük, hogy az ismeretek a különböző területeken egymásra épülve, egymás kölcsönhatásában vagy egymástól függetlenül alakultak ki.

A legkorábbi időpont, melyet történeti kormeghatározással pontosan be tudunk azonosítani, Kr. e. 3100, az egyiptomi első dinasztia uralma, melyre egy keltezhető csillagászati esemény alapján tudtak következtetni, amit több mint egy évezreddel később jegyeztek fel. Az időszámításunk előtti harmadik évezredet megelőző korokra vonatkozóan a régészet csaknem kizárólag a radiokarbon kormeghatározásra van utalva; ezzel az eljárással a keltezhetőség határát mintegy 50-80 ezer évre sikerült kitolni. A módszer csak széntartalmú anyagok esetében alkalmazható, és nem alkalmazható a 80 ezer évnél idősebb minták esetében sem, illetve kis széntartalmú anyagokból (agancs, csont, kagylóhéj) nagyobb tömegú minta szükséges a módszerhez, amit a régész a legtöbb esetben nem engedhet meg magának. Az aminosav racemizáción alapuló kormeghatározás 1-2 gramm jól konzerválódott vagy fiatalabb minták esetében 100-500 milligramm fehérjetartalmú anyagból is elvégezhető. Ez utóbbi módszer igen nagy előnye még az is, hogy a kormeghatározás idejét fél millió évig is ki lehet tolni, tehát ez a módszer még ott is használható, ahol a radiokarbon kormeghatározás már szóba sem jöhet. 
Fentiek miatt régész kollégáink ösztönzésére az izoleucin epimerizációját és a többi fehérjealkotó aminosav racemizációját felhasználva új módszert dolgoztunk ki fossziliák korának meghatározására. Az általunk kidolgozott, munkahelyünk adottságaihoz alkalmazott, aminosav racemizáción, illetve epimerizáción alapuló kormeghatározási módszer egy olyan vizsgálat, melyet hazánkban - tudomásunk szerint - még senki sem alkalmazott, a fehérjealkotó aminosavak többségét pedig mi használtuk fel elsőként a világon - csoportosan - kormeghatározásra. Segítségével adatokat kaphatunk régen élt emberek és állatok csontjai koráról, segítve ezzel a régész munkáját. A D-allo-izoleucin és a "lassú" racemizációs idejủ aminosavakkal a 100.000-500.000 év közti fehérjetartalmú régészeti leletek, a "gyors" és "közepes" racemizációs idejű aminosavak segítségével pedig az 5.000-100.000 év közötti csontleletek korát tudtuk az analitikai módszer hibahatárának (D-allo-izoleucin esetében 3\%, a többi aminosav esetében 5-10\%) meghatározni. A D- és az L-aminosavak szétválasztására és meghatározására a nagyhatékonyságú folyadékkromatográfiát, a királis szilikagélen történő elválasztás és denzitometriás meghatározást és egy általunk kidolgozott, a diasztereomer dipeptidek szétválasztásán alapuló ioncserés oszlopkromatográfiás módszert használtuk fel.

\section{Az aminosav racemizáció alkalmazása kormeghatározásra}

1860-ban Pasteur optikai aktivitást mutató aszparagint vizsgált bükkönyből. ${ }^{1}$ További munkássága alapján megállapította, hogy a növényi és állati életben legfontosabb szerepet játszó vegyületek legtöbbje aszimmetrikus, és csak az aszimmetrikus vegyületek rendelkeznek optikai aktivitással. Terentev és Klabunovszkii leszögezték, ${ }^{2}$ hogy az élet nem lehet és soha nem is lehetett molekuláris diszimmetria nélkül. Bizonyosan létezik kapcsolat az optikai aktivitás és az élet között, hisz minden fehérje kizárólag L-enantiomer aminosavakból épül fel, míg a természetes cukrok konfigurációja D. Az élet keletkezését szimuláló különböző kísérletekben a primitív redukáló atmoszférát utánozva több aminosavat sikerült szintetizálni, ezek az aminosavak azonban racémek voltak, ezekben a kísérletekben egyik enantiomer sem került előnybe a másikkal szemben. ${ }^{3}$ 1908ban Van't Hoff, ${ }^{4}$ majd 1934-ben Karagunis és Drikos képesek voltak ${ }^{5}$ optikailag aktív vegyületeket szintetizálni körkörösen polarizált fény segítségével. E kísérleteknek szépséghibája azonban az, hogy a polarizált fény csak igen szélsőséges esetekben fordul elő a természetben, így például $\beta$-bomlás során kibocsájtott $\gamma$-sugárzás hatására. ${ }^{6}$ Többen beszámoltak a D- illetve L-aminosavak kedvezményezett szintéziséről vagy bomlásáról $\beta$-részecskékkel, illetve polarizált elektronokkal történő bombázás során.

1968-ban Ponnamperuma és Gabel különböző geológiai üledékeket vizsgálva leszögezték, ${ }^{7}$ hogy az üledékben előforduló optikailag aktív szerves molekulák egyértelmű bizonyítékai az élet létezésének az üledék kialakulásakor. Ez természetesen csak akkor igaz, ha az optikailag aktív szerves vegyületek nem racemizálódtak az elmúlt idő alatt. Az elmúlt 35-40 év alatt többen vizsgálták a meteoritok és a holdkőzet minták aminosav tartalmát. Több - minden bizonnyal abiotikus úton keletkezett - aminosavat is kimutattak ezekben az anyagokban, az optikai aktivitás vizsgálat azonban minden esetben negatív eredményt hozott. ${ }^{8}$

Az őskori kagylókban, csontokban és fogakban lévő aminosavakról az első beszámolót Abelson írta 1954ben. ${ }^{9}$ A legidősebb általa vizsgált kövület, a Devon korból származó halcsont 360 millió éves kora ellenére tartalmazott glicint, alanint, glutaminsavat, leucint, valint és aszparaginsavat. Laboratóriumi kísérletekben megállapította, hogy ezek az aminosavak a legállandóbbak, és megfelelő hőmérsékleti körülmények között akár több millió éves túlélésre is képesek. 1955-ben ő tesz elsőnek javaslatot a kövületekben lévő fehérjék lebomlásának kormeghatározásra történő felhasználására. Ugyancsak ő javasolja elsőként a fehérjebomlás és hőmérsékletbecslés összekapcsolását, tehát ő tekinthető a geotermometria egyik előfutárának is. Vizsgálatainak eredményeit az 1. táblázat tartalmazza.

Az aminosavak hőbomlásának tanulmányozása után Vallentyne egy új geotermikus módszer kidolgozására tesz javaslatot, ${ }^{10}$ mely módszer az aminosavak szelektív bomlásán alapszik. Szabad aminosavak 0.01 mólos vizes oldatát $210-280^{\circ} \mathrm{C}$ között tanulmányozva az aminosavakat elbomlási sorrendjüknek megfelelően 5 csoportba osztotta. Az első csoportba tartoznak a könnyen bomló, míg a 4-5. csoportba a nehezebben bomló aminosavak. A különböző csoportokba tartozó aminosavakat az alábbi összeállítás tartalmazza:

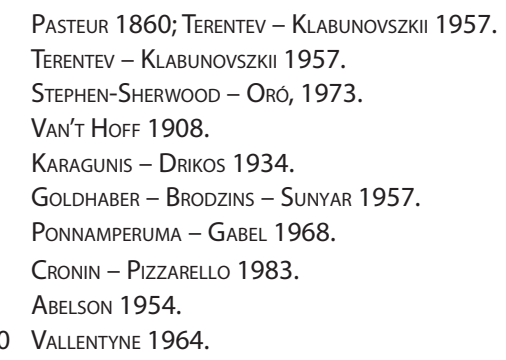


1. Aszparaginsav, cisztin, treonin, szerin, arginin

2. Lizin, hisztidin, metionin

3. Tirozin, glicin, valin, leucin, izoleucin

4. Alanin, prolin, hidroxiprolin

5. Glutaminsav

\begin{tabular}{|l|c|c|c|}
\hline \multicolumn{1}{|c|}{ Megnevezés } & Becsült kor (év) & $\begin{array}{c}\text { Aminosav } \\
\text { tartalom } \\
(\boldsymbol{\mu} \mathbf{M} / \mathbf{g})\end{array}$ & Legfontosabb alkotórészek \\
\hline Plesippus (történelem előtti ló) & $\begin{array}{c}\text { Késő Pliocén } \\
500.000\end{array}$ & 0,6 & Ala, Gly \\
\hline Plesippus (fog) & $\begin{array}{c}\text { Késő Pliocén } \\
500.000\end{array}$ & 0,31 & Gly, Ala, Leu, Val, Glu \\
\hline Mesohippus (fog) & $\begin{array}{c}\text { Oligocén } \\
40.000 .000\end{array}$ & 0,3 & Ala, Gly \\
\hline Nasasaurus (dinoszaurusz) & $\begin{array}{c}\text { Kréta } \\
100.000 .000\end{array}$ & 1,8 & Ala, Gly, Glu, Leu, Val \\
\hline Stegosaurus (dinoszaurusz) & Jura & 0,26 & Ala, Gly, Glu \\
\hline Dinichtys (hal) & Devon & 360.000 .000 & Gly, Ala, Glu, Leu, Val, Asp \\
\hline
\end{tabular}

1. táblázat. A különböző fossziliák aminosav tartalma

Hare és Abelson 1967-ben közölték, ${ }^{11}$ hogy a kövületekben található D-aminosavak feltételezhetően a fehérje L-aminosavainak bomlásából származnak. Növekvő korú megkövesedett kagylók aminosav összetételét vizsgálva megállapították, hogy növekvő korral nő a D-aminosavak aránya az L-aminosavakhoz viszonyítva. A legöregebb általuk vizsgált miocén korú kövületben az aminosavak már csak racém formában fordultak elö. Az L-izoleucin racemizációját tanulmányozta magas hőmérsékleten Hare és Mitterer 1968-ban. ${ }^{12}$ Kísérleteik eredményeit alkalmazva egy megkövesedett kagylóhéj D-allo-izoleucin és L-izoleucin arányát 0,32-nek találva a kövület korát 70.000 évre becsülték. Ez volt az aminosav racemizáció (itt helyesebben epimerizáció) első konkrét alkalmazása a geokronológiában.

Ezt követően az aminosav racemizációt szinte minden fehérjetartalmú anyag korának meghatározására kezdték alkalmazni. Többek között alkalmazták üledékek, ${ }^{13}$ kagylók, ${ }^{14}$ csontok$^{15}$ fogak $^{16}$ és korallok ${ }^{17}$ korának megállapítására, és a kövület keletkezése óta eltelt időszak hőmérsékletének becslésére. ${ }^{18}$

Az előzőleg említett szerző́k felfedezései óriási lendületet adtak az aminosav racemizáción alapuló kormeghatározásnak. Az alaposabb kutatómunka kiderítette azonban azt is, hogy a módszernek - hasonlóan a többi kormeghatározási módszerhez - számos hibája van, és az eredmények helytelen értelmezése téves következtetésekre vezethet. A módszer fejlesztésére és alkalmazására végzett legjelentősebb munkákat az alábbiakban foglaljuk össze.

A fossziliákból mért D- és L-aminosavak arányának értéke függ attól, hogy milyen módszert alkalmaznak az aminosavak kivonására és meghatározására. Különböző eredményeket kaphatunk a szabad, a fehérjében kötött vagy az összes aminosav vizsgálatakor, de az eltérés oka lehet az enzimes-, a gázkromatográfiás- vagy a nagyhatékonyságú folyadékkromatográfiás módszerek közötti, a módszer sajátságából eredő hiba is.

11 HARE - ABELSON 1967.

12 Hare - MitTerer 1968.

13 BADA - LUYENDYK - MAYNARD 1970; WeHMiller - Hare 1971.

14 HARE - MitTERER 1968.

15 Bada 1972a; DungWorth - VinCKEN - SCHWARTZ 1974.

16 Helfman - Bada 1975; Helfman - Bada 1976.

17 Wehmiller - Hare - Kujala 1976.

18 Bada - Kvenvolden - Peterson 1973; Schroeder - Bada 1973. 
Az aminosavak izolálására a fossziliákból az elmúlt években különböző eljárásokat dolgoztak ki, melyek elég sok azonos elemet tartalmaznak. Általános a minta mechanikai tisztítása, mosása, és az ultrahang használata a hozzátapadt szennyező anyagok eltávolítására. ${ }^{19}$ A mintát ezt követően szárítják és megőrlik, majd az így kapott homogén őrlemény már kész az aminosavak extrakciójára. A mintát mossák híg sósavval a szabad aminosavak kioldására, majd a szabad aminosav tartalmú oldatot szűréssel eltávolítják az aminosavakat kötött állapotban tartalmazó oldhatatlan maradéktól. ${ }^{20}$ A szabad aminosavak - esetleg sómentesítés után - ekkor már készek a D- és L-aminosavak meghatározására.

Az oldhatatlan maradékot az aminosav analitikában általánosan használatos 6 mólos sósavval 22-24 órán át 100-110 C-on hidrolizálják, a hidrolízis befejeztekor a sósavat bepárlással eltávolítják, a maradékot desztillált vízben feloldják, majd sómentesítik. A sómentesítésre egyesek a hidrogénfluoridos lecsapást (a kalcium eltávolítása), ${ }^{21}$ mások pedig a hidrolizátum kation-, illetve anioncserélő gyantán történő átvezetését alkalmazzák. ${ }^{22}$ Nem szerencsés a minta előkészítése és az aminosavak kinyerése közben lúgos kezelést alkalmazni, mert az aminosavak lúgos hatásra igen hajlamosak a racemizációra, és azt az előkészítés folyamán mindenképpen kerülni kell.

Az aminosav enantiomerek szétválasztására és meghatározására több módszert is kidolgoztak. Kezdetben használták a polarimetriát, amit elsősorban tiszta aminosavak racemizációjának tanulmányozására alkalmaztak. ${ }^{23}$ Enzimes technikát használtak a D- és L-aminosavak meghatározására talajból Aldag és munkatársai, ${ }^{24}$ és néhány fossziliákból Hare és Abelson, ${ }^{25} \mathrm{Hare}^{26}$ és Petit. ${ }^{27}$ Ennek az eljárásnak a lényege a D- vagy az L-aminosavak oxidációja, majd az ezt követő aminosav meghatározás. A módszer hibája, hogy nem használható a D-aminosavak nyomnyi mennyiségeinek kimutatására, és igen jelentős hibaforrás lehet az enzimekből származó L-aminosavakkal történő szennyezés.

Az optikailag aktív (királis) aminosavak reakciója királis reagensekkel diasztereomer vegyületet eredményez, melyek elvben nem királis oszlopon is szétválaszthatók. Amennyiben a királis reagens egy másik aminosav, akkor a diasztereomer dipeptidek elválasztása és meghatározása ioncserés oszlopkromatográfiával is megoldható. Manning és Moore ${ }^{28}$ valamint Csapó és munkatársaii ${ }^{29}$ ioncserés oszlopkromatográfiás eljárást írtak le a D- és L-aminosavak szétválasztására. Az eljárás lényege egy L-aminosav N-karboxi anhidridnek illetve aktív észternek a vizsgálandó D- és L-aminosavakkal lejátszódó reakciója, melynek során diasztereomer dipeptidek keletkeznek, melyek alkalmasak az ioncserés szétválasztásra. Manning és Moore módszerével Bada és Protsch rutinszerűen analizált ${ }^{30}$ csontból aszparaginsavat L-Leu-D-Asp és L-Leu-L-Asp diasztereomer dipeptid formájában.

AD-ésL-aminosavakszétválasztásáraazegyiklegjobbmódszer-anagyhatékonyságúfolyadékkromatográfia mellett - a gázkromatográfia. Az enantiomereket szét lehet választani egy megfelelő aszimmetrikus reagenssel létrehozott diasztereomer-pár formában, vagy az illékonnyá tett származékokat egy optikailag aktív álló fázison kell szeparálni. Charles és munkatársai az N-trifluoracetil-( \pm )-2-n-alkoholokat használták a diasztereomerek képzésére. ${ }^{31}$ Ezt a módszert tökéletesítették (+)-2-n-butanol alkalmazásával Pollack és munkatársai, ${ }^{32}$ és tették alkalmassá a szerves geokémia számára Kvenwolden és munkatársai 1971-ben. ${ }^{33}$ Az elsőnek alkalmazott optikailag aktív stacionáris fázis a gázkromatográfiában az N-trifluor-acetil-L-izoleucin-lauril észter volt, melyet Gil-Av és munkatársai szintetizáltak 1966-ban. ${ }^{34}$ Charles és munkatársai az N-lauril-L-valil-tercier-butilamidot alkalmazták és találták nagyon jónak az optikai izomerek szétválasztására. ${ }^{35} \mathrm{~A}$ gázkromatográfiás technikát ma már olyan tökéletesre fejlesztették, hogy az enantiomerek meghatározásának hibája kisebb, mint 5\%, és a reprodukálhatóság is rendkívül jó.

Újabban az enantiomerek szétválasztására és meghatározására egyre inkább teret nyer - az előzőekben említett módszerek rovására - a nagyhatékonyságú folyadékkromatográfia. Weinstein és Weiner az aminosa-

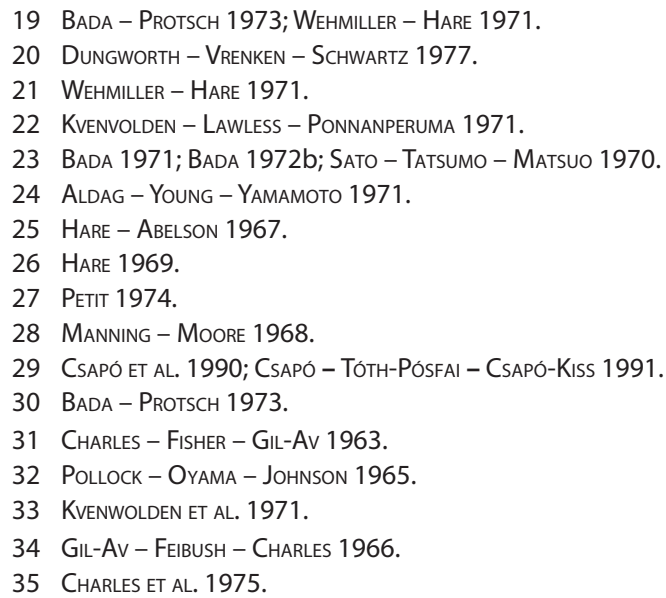


vakból az 5-dimetil-aminonaftalin-1-szulfonil fluoreszkáló származékot képezték és fordított fázisú folyadékkromatográfiával az N,N'-di-n-propil-L-alanin (L-DPA) és réz acetát királis töltet alkalmazásával az összes fehérjealkotó aminosav D- és L-enantiomerjét szét tudták választani egy mintából. ${ }^{36}$ Véleményük szerint a módszer mennyiségi meghatározásra kiváló, érzékeny, gyors, a módszer továbbfejlesztése során az aminosav analízishez hasonló módszerré alakulhat.

Marfey ugyancsak nagyhatékonyságú folyadékkromatográfiás módszert fejlesztett ki az enantiomerek szétválasztására. ${ }^{37} \mathrm{Az}$ 1-fluor-2,4-dinitrofenil-5-L-alanin-amid segítségével - mely egy igen reakcióképes fluor atomot tartalmaz - diasztereomer származékokat hozott létre D- és L-aminosavak keverékéből. Ezeket a származékokat nagynyomású folyadékkromatográfiával trietil-aminfoszfát és acetonitril eluensek megfelelő gradiensét alkalmazva igen jó eredménnyel szét tudta választani és mennyiségileg meghatározni. Közleményében a D- és L-aszparaginsav, glutaminsav, metionin, alanin és fenilalanin elegyének szétválasztását közli, de a feltételek megfelelő változtatásával lehetőség van a többi aminosav enantiomer szétválasztására is.

Biológiailag aktív anyagok optikai tisztaságának ellenőrzésére Knabe, ${ }^{38}$ Gübitz és Mihellyes ${ }^{39}$ Gübitz és munkatársai ${ }^{40}$ egy direkt módszert dolgoztak ki nagyhatékonyságú folyadékkromatográfiával. A módszer lényege a királis oszlop, mely kémiailag kötött L-hidroxiprolin- $\mathrm{Cu}^{2+}$ komplexből áll. A mozgó fázis $\mathrm{Cu}^{2+}$ tartalmú vizes oldat. A fenti stacionáris fázis alkalmazásával mód nyílik mindazon vegyületek optikai tisztaságának ellenőrzésére, melyek kelát komplexeket képeznek a $\mathrm{Cu}^{2+}$ ionokkal, amilyenek például az aminosavak. A módszer hibája az előzőekben említettekhez képest az, hogy egyszerre csak egy aminosav D- és L-alakját lehet vele meghatározni.

Az aminosav enantiomerek mennyiségi meghatározásához nem elég csak az enantiomereket egymástól elválasztani, de ügyelni kell arra is, hogy az enantiomerek a többi aminosavtól vagy azok származékaitól is jól elkülönüljenek. Ezen túl, a megfelelő érzékenység elérésére kis mennyiségben is jól detektálható aminosav származékot kell képezni. Az utóbbi időben erre a célra széles körüen alkalmazták a fluoreszcens reagensekkel történő oszlop előtti származékképzést és a származékok fordított fázisú kromatográfiáját (RPC). E módszereknél a kimutathatóság határa a meghatározni kívánt aminosavaknál igen kicsi, és az analitikai rendszer flexibilitása is rendkívüli előnyöket rejt magában. ${ }^{41}$ Így többek között automatikus módszereket fejlesztettek ki az optikailag inaktív o-ftálaldehid/merkaptoetanollal (OPA) az $\alpha$-aminosavak ${ }_{1}{ }^{42}$ a 9 -flurenilmetil kloroformáttal (FMOC-Cl) pedig az $\alpha$-aminosavak és az iminosavak együttes meghatározására. ${ }^{43} \mathrm{~A}$ királis reagenssel történő származékképzés után lehetőség van a fehérjeépítő aminosavak enantiomerjeinek szétválasztására és meghatározására egyetlen analízis során RCP-vel.

Mivel a kromatográfiás elválasztás általában 50-70 percet is igénybe vesz, nagyon fontos, hogy a kidolgozott analitikai módszer teljesen automatikus legyen. Előfeltétel még az egyszerű származékképzési reakció, mely szobahőmérsékleten rövid idő alatt végbemegy. Az optikailag aktiv tiolok és az OPA valamint a meghatározni kívánt aminosavak közti reakciót felhasználták aminosav enantiomerek szétválasztására és meghatározására. ${ }^{44} \mathrm{~A}$ királis 1-(9-fluorenil)etil kloroformát (FLEC) használata az enantiomerek szétválasztására azzal az előnnyel is jár, hogy az nemcsak az $\alpha$-aminosavakkal, de az iminosavakkal is stabil származékot képez. ${ }^{45}$

Külön említést érdemel a geokronológiában való igen gyakori alkalmazása miatt a D-allo-izoleucin analitikája. A hidroxiprolin és a treonin mellett az izoleucin az, amely két aszimmetria centrummal rendelkezik. Az izoleucinból az idők folyamán keletkező D-allo-izoleucin - mely az izoleucin diasztereomerje - a rutinszerűen alkalmazott ioncserés aminosav elválasztás során az izoleucin és a metionin között jelenik meg a kromatogrammon, azoktól jól elváló, jól értékelhető csúcsot ad. Az $\alpha$-helyzetű szénatom racemizációját, a D-allo-izoleucin képződését a peptidszintézis folyamán igen behatóan tanulmányozta Bodanszky és Conklin. ${ }^{46}$ Vizsgálták többek között a sósavas hidrolízis és a különböző harmadrendű aminok hatását a racemizációra.

Nagyon fontos annak ismerete is, hogy a fehérje hidrolízise során történik-e racemizáció, hisz - amennyiben igen - az a mérési eredményeket meghamisíthatja. Különböző tanulmányok beszámoltak arról, hogy a racemizáció foka a hidrolízis folyamán függ a peptid, illetve a fehérje típusától, az aminosav környezetében levő többi aminosavtól, és megállapították, hogy a peptidkötésben lévő aminosavak általában gyorsabban

36 Weinstein - Weiner 1984.

37 Marfey 1984.

38 KNABE 1984.

39 GÜBitZ - Mihellyes 1984.

40 GÜBITZ - JufFMANn - JelLenz 1982

41 Lindroth - Mopper 1979; Tapuhi et Al.1981; EINARSSON et Al. 1987.

42 SMITH - PACINO 1985.

43 Cunico et Al. 1986; Betner - FöldI 1988.

44 Aswad 1984; Buck - Krummen 1987.

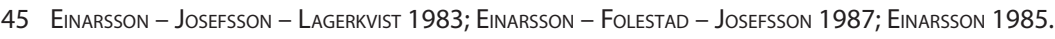

46 BODANSZKY - CONKLIN 1967. 
racemizálódnak a szabad aminosavaknál. ${ }^{47}$ Wiltshire az L-glutaminsavat 6 mólos sósavval 24 órán refluxáltatva azt tapasztalta, ${ }^{48}$ hogy annak mintegy 3-5\%-a átalakul D-glutaminsavvá. Ló mioglobint és marha inzulint hidrolizálva 6,6-4,6 \%-ban kapott D-glutaminsavat. Manning és Moore a szabad és a peptidkötésben lévő aminosavak racemizációját vizsgálva megállapították, ${ }^{49}$ hogy néhány aminosavnál különbözik a savas hidrolízisnél mért racemizáció attól függően, hogy szabad vagy peptidkötésben lévő aminosavról van szó, és attól függően is, hogy a peptidláncban milyen aminosavak között helyezkedik el a kérdéses aminosav. Manning egyértelműen leszögezi, ${ }^{50}$ hogy szabad L-aminosavat használva kontrollként nem lehet egyértelműen jelezni a racemizáció fokát, mely a fehérjehidrolízis során fellép. Fentiek ellenére a szabad aminosavak sósavas kezelését a fehérje hidrolízise során fellépő racemizáció becslésére többen alkalmazták a geokronológiában. A szerzők többsége 0,1 és 3,7\% közötti racemizációt állapított meg ezekben a kísérletekben a különböző aminosavakra. Bada és Protsch egy mai csont D- és L-aszparaginsav arányára 0,07-et kapott savas hidrolízist követve. ${ }^{51}$ Felhívják a figyelmet arra, hogy a hidrolízis folyamán bekövetkező racemizációt a kor kiszámításánál feltétlenül figyelembe kell venni, ezzel az értékkel korrigálni kell a kapott D- és L-aminosav arányokat. A különböző szerzők által szabad aminosavakra, illetve fehérjében kötött aminosavakra kapott racemizáció értékeket a 2. táblázat ${ }^{52}$ és a 3. táblázat ${ }^{53}$ tartalmazza.

\begin{tabular}{|c|c|c|c|c|c|c|c|c|c|c|c|c|c|c|}
\hline Sorszám & $\begin{array}{l}\text { Hidrolízis } \\
\text { körülmé- } \\
\text { nyek }\end{array}$ & $\begin{array}{c}\text { Idó } \\
\text { (óra) }\end{array}$ & \multicolumn{9}{|c|}{ Aminosavak } \\
\hline 1 & Reflux & & Ser & Ala & Arg & Val & Leu & Ile & Glu & Phe & Pro & Asp & Lys & Met \\
\hline 2 & $105^{\circ} \mathrm{C}$ & 6 & - & 22 & - & 19 & 5 & - & - & - & - & - & - & - \\
\hline 3 & $120^{\circ} \mathrm{C}$ & 24 & - & 1,1 & - & 0,3 & 1,3 & 0,5 & - & - & - & - & - & - \\
\hline 4 & $110^{\circ} \mathrm{C}$ & 24 & - & 3,7 & - & 0,6 & 2,1 & 1,4 & - & - & - & - & - & - \\
\hline 5 & $110^{\circ} \mathrm{C}$ & 24 & - & 0,5 & - & 0,2 & 0,8 & 0,3 & 1,9 & 0,1 & 1,7 & 1,7 & - & - \\
\hline 6 & $110^{\circ} \mathrm{C}$ & 22 & 0,4 & - & 1,6 & - & - & - & - & 1,4 & 2,2 & - & - & - \\
\hline 7 & $110^{\circ} \mathrm{C}$ & 18 & 0,5 & - & - & - & - & - & 3,3 & - & - & 3,7 & - & - \\
\hline 8 & $110^{\circ} \mathrm{C}$ & 22 & 0,4 & 1 & 1,6 & 0,7 & 1,3 & 1 & & & 2,2 & & 3 & 2,2 \\
\hline
\end{tabular}

2. táblázat. A szabad aminosavak racemizációja a 6M sósavas hidrolízis folyamán (\%)

\begin{tabular}{|c|c|c|c|c|c|c|c|c|c|c|c|c|c|}
\hline & A fehérje & \begin{tabular}{|c|} 
Hidrolízis \\
hömér-
\end{tabular} & \begin{tabular}{|l} 
Hidro- \\
lízis idő
\end{tabular} & \multicolumn{10}{|c|}{ Aminosavak } \\
\hline & & & & Ala & Glu & Val & Ile & Leu & Pro & Arg & Phe & Asp & Ser \\
\hline 1 & Bradikinin & 110 & 22 & - & - & - & - & - & 2,4 & 1,7 & 3,9 & - & - \\
\hline 2 & Ribonuklezáz & 110 & 18 & - & 4,2 & - & - & - & - & - & - & 4,4 & 0,2 \\
\hline 3 & $\begin{array}{c}\text { Mamut kolla- } \\
\text { gén }\end{array}$ & 105 & 24 & 1,2 & 2,7 & 0,7 & - & 1,6 & - & - & $2,6^{*}$ & 3 & - \\
\hline 4 & Ló mioglobin & Reflux & 24 & - & 6,6 & - & - & - & - & - & - & - & - \\
\hline 5 & Marha inzulin & Reflux & 24 & - & 4,6 & - & - & - & - & - & - & - & - \\
\hline
\end{tabular}

3. táblázat. A peptidkötésben lévő aminosavak racemizációja a 6M sósavas hidrolízis folyamán (\%)

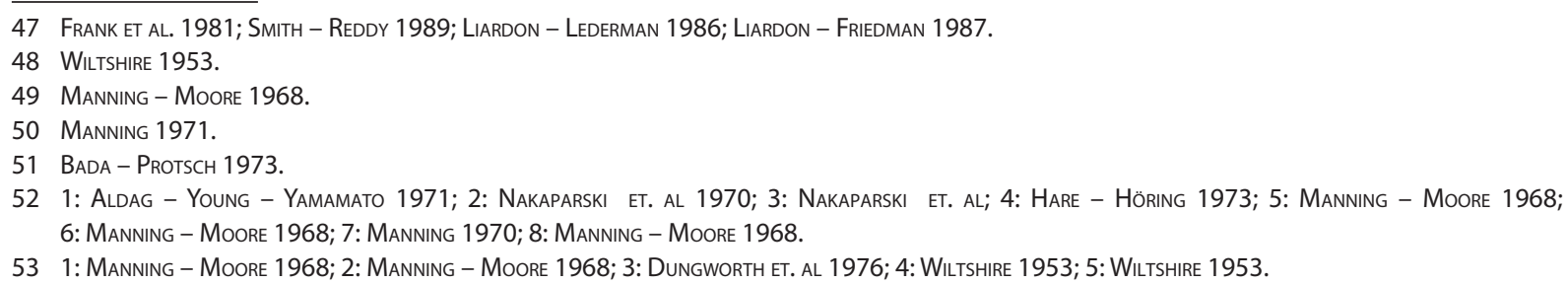


Az utóbbi időben többen kísérleteztek a mikrohullámú technológia alkalmazásával a fehérje hidrolízise során,$^{54}$ és többen beszámoltak a rövid ideig magas hőmérsékleten végzett hidrolízissel kapott kiváló eredményekről is..$^{55}$ Úgy túnik, hogy a mikrohullámmal végzett hidrolízis folyamán jelentős racemizáció lép fel, hisz a mikrohullámú kezelést aminosav racemizáció kiváltására is használták. ${ }^{56}$ Nem okoz gondot a racemizáció akkor, ha nem kívánjuk az aminosav enantiomereket meghatározni, hanem megelégszünk az összes aminosav tartalom meghatározásával. Amennyiben célunk az aminosav enantiomerek szétválasztása és meghatározása, olyan fehérjehidrolízis módszert kell választani, melynek során minimális a racemizáció, hisz a hidrolízis alatt fellépő számottevő racemizáció esetén nem tudjuk eldönteni, hogy az aminosav enantiomerek egy része eredetileg is benne volt a mintában, vagy csak a hidrolízis folyamán keletkezett. Több módszert dolgoztak ki a fehérjehidrolízis során bekövetkező racemizáció visszaszorítására, ${ }^{57}$ azonban ezek hosszadalmasak, illetve nehézkesek voltak. Fentiek miatt egy magas hőmérsékleten és rövid ideig végzett fehérje hidrolízis módszert dolgoztunk ki a lehető legkisebb racemizáció elérésére a hidrolízis folyamán. Hibaforrást jelenthet a savas hidrolízisnél még az, hogy az aszparagin és glutamin a hidrolízis folyamán aszparaginsavvá és glutaminsavvá alakul át. Nem alakult ki egységes vélemény azt illetően, hogy vajon a fossziliák tartalmazzák-e a két savamidot, mennyi ezek dezaminációs ideje és vajon milyen hibát okozhatnak ezek a vegyületek a kormeghatározásban.

Bada meghatározta ${ }^{58}$ néhány aminosav racemizációs, illetve az izoleucin epimerizációs felezési idejét 7.6 pH értéknél 0 és $25^{\circ} \mathrm{C}$-on. Az általa vizsgált aminosavak közül a leggyorsabb racemizációs idejű fenilalanin felezési ideje $25^{\circ} \mathrm{C}$-on 2000 év, $0^{\circ} \mathrm{C}$-on 160.000 év. Ugyanezek az értékek az aszparaginsavnál 3.500 és 430.000 évnek, az alaninnál 12.000 és 1.400 .000 évnek, az izoleucinnál pedig 48.000 és 6.000 .000 évnek adódtak. Kísérleti eredményei bizonyították azt a peptidkémikusok által már régóta ismert tényt, hogy legkönnyebben azok az aminosavak racemizálódnak, amelyek aromás oldalláncot (tirozin, fenilalanin) vagy indol- és imidazolcsoportot (triptofán, hisztidin) tartalmaznak, és legnehezebb racemizációra bírni az apoláros oldalláncot tartalmazó valint, izoleucint és leucint.

Bada és Protsch az aszparaginsav hidrolízis alatti racemizációját vizsgálva összefüggést állapított meg ${ }^{59}$ a hidrolízis közbeni racemizáció és a becsült kor között. Vizsgálataik eredményeit a 4. táblázat tartalmazza. A táblázat adataiból látható, hogy egy százalékos racemizáció a hidrolízis folyamán az aszparaginsav esetében 700 évvel hamisítja meg a kormeghatározást.

\begin{tabular}{|c|c|c|c|c|c|c|c|}
\hline $\begin{array}{c}\text { A hidrolíziskor keletke- } \\
\text { zett D-Asp mennyisége } \\
\text { (\%) }\end{array}$ & $\mathbf{0}$ & $\mathbf{1}$ & $\mathbf{2}$ & $\mathbf{3}$ & $\mathbf{4}$ & $\mathbf{5}$ & $\mathbf{6 , 5}$ \\
\hline Számított idő (1.000 év) & 22,4 & 21,7 & 21 & 20,3 & 19,6 & 18,8 & 17,7 \\
\hline
\end{tabular}

4. táblázat. A fehérjehidrolízis során lejátszódó racemizáció hatása a fosszilis csontok korára (BADA - PROTSCH 1973. nyomán)

Neuberger az aminosavak bázis katalizálta racemizációjára az alábbi mechanizmust írta le. ${ }^{60}$ Első lépésként az $\alpha$ helyzetú protont egy bázis elvonja és a tetraéderes konfigurációból egy planáris szerkezetű anion jön létre, mely a továbbiak során egy proton fölvételével stabilizálódik. Neuberger szerint bármilyen helyettesítés a karboxil csoporton fokozza a racemizációt, mivel ez megkönnyíti az $\alpha$-helyzetú proton leszakadását és hasonló hatás érhető el akkor is, ha a $\beta$-helyzetű szénatomhoz egy elektronegatív szubsztituenst kapcsolunk. Manning bizonyította az $\alpha$-helyzetű proton elvonást és rekombinálódást, mint a racemizáció első lépését az $\alpha$-helyzetbe beépült tricium mérésével. ${ }^{61}$ További vizsgálatok során a fentiekben leírt neubergeri megállapítások megerősítést nyertek, és Smith és munkatársai egyértelműen leszögezték, ${ }^{62}$ hogy a relatív racemizációs arányt egy fehérjében több tényező (sztérikus, szomszéd, oldószerhatás) együttes hatását figyelembe véve lehet csak becsülni.

54 Chen et al. 1987; Woodward - Gilman - Engelhart 1990; Gilman - Woodward 1990; Pickering - Newton 1992.

55 ChIOU - Wang 1988; CSAPÓ Et AL. 1994.

56 CHEN - Wu - WANG 1989.

57 D'aniello - Giuditta 1980; Smith - Khatib - Sudhakar Reddy 1983; Reddy et Al. 1989.

58 BADA 1971

59 BADA - PROTSCH 1973.

60 Neuberger 1948.

61 Manning 1970.

62 Smith et al. 1976. 
Neuberger egy másik elképzelése, miszerint a peptidkötésben lévő aminosavak racemizációja lényegesen gyorsabb mind a sav, mind a bázis katalizálta reakciókban, mint a szabad aminosavakban ugyancsak bizonyítást nyert a későbbiek folyamán. Fentiekből az a következtetés adódik, hogy a dipeptidben lévő aminosavak gyorsabban racemizálódnak, mint a szabad aminosavak, és a növekvő racemizációs sebesség a peptidlánc hosszának növekedésével még tovább növekszik. Ebből adódóan feltétlenül kell ismerni a szabad és a kötött állapotban lévő aminosavak racemizációs folyamatait.

Fentieknek homlokegyenest ellentmond az a megfigyelés, hogy a kövületekben és üledékekben a szabad aminosavak jobban racemizálódnak mint a fehérjében kötött aminosavak. ${ }^{63}$ Ezt Hare azzal magyarázta, ${ }^{64}$ hogy a fehérjelánc szétszakadásakor az aktivált állapotban lévő aminosavak nagyobb hajlandóságot mutatnak a racemizációra mint a kötöttek. Bada és Schroeder szerint ${ }^{65}$ viszont sokkal valószínúbb az a mechanizmus, hogy a fehérjéből származó szabad aminosavak racemizációját a nyomnyi mennyiségben jelenlévő nehézfém-ionok katalizálják, tehát nyilvánvaló, hogy az aminosavak fossziliákban történő racemizációja egy igen bonyolult és összetett folyamat, melyet befolyásol a hidrolízis és a katalitikus hatás is. ${ }^{66}$ Fentiekből az is következik, hogy a szabad aminosavak, a peptidek és a fehérjék más és más arányú racemizáción mennek keresztül, és a három frakció közül a fehérjék a legstabilabbak a racemizáció tekintetében, hiszen kevésbé hajlamosak a fémek általi katalízisre. A szabad aminosavak racemizációját elsősorban a $\mathrm{pH}^{67}$ és a fémionok $\left(\mathrm{Ca}^{2+}, \mathrm{Mg}^{2+}\right)$ befolyásolják. Smith és munkatársai bizonyították, ${ }^{68}$ hogy az ionerősség is jelentős tényező, hiszen növekvő ionerősség hatására növekszik a racemizáció is.

Értékelve az elmondottakat leszögezhető, hogy más a racemizáció a szabad, a peptidben lévő, avagy a fehérjében kötött aminosavaknál, és e három frakciónál a racemizációt a különböző környezeti hatások másként befolyásolják. Úgy túnik, hogy a fehérjében kötött aminosavak racemizációjára van a legkisebb hatással a pH és az ionerősség, tehát a három frakció közül ez a legmegbízhatóbb a kormeghatározás tekintetében. Az a tény viszont, hogy lúgos körülmények között a racemizációs folyamatok felgyorsulnak, felhívja a figyelmet arra, hogy a fehérje kinyerés folyamatából a lúgos extrakciót lehetőleg el kell hagyni. Az elmondottaknak nem mond ellent az sem, hogy a szabad aminosav, illetőleg peptidfrakció is értékes információt szolgáltathat a régész számára.

\section{Anyag és módszer}

\section{Nagyhatékonyságú folyadékkromatográfia a D-és L-aminosavak szétválasztására és meghatározására}

Az aminosav enantiomerek szétválasztása és meghatározása az 1-(9-fluorenil) etil kloroformáttal történő származékképzés után fordított fázisú folyadékkromatográfiával

A készülék. Az alkalmazott Varian 5500 LC gradiens képzésre alkalmas rendszerrel, Varian 9090 mintaadagolóval és gázmúködtetésű, $10 \mu \mathrm{l}$-es hurokkal ellátott Valco injektorral rendelkezett. Shimadzu RF-535 fluoreszcenciás detektort használtunk a származékok mennyiségének mérésére; a gerjesztési és az emissziós hullámhossz 260 és $315 \mathrm{~nm}$ volt. Az elválasztás folyamatának és az automatikus mintaadagoló munkájának ellenőrzésére, a mintafelvitelre és a kromatogramok tárolására a Varian DS 651 vezénylő rendszert használtuk. Az automatikus mintaadagolóhoz szükséges ampullákat a Varian cégtől (Solna, Sweden) szereztük be.

Vegyszerek. A FLEC reagenst az EKA-Nobel (Surte, Sweden), az aminosav standardot a Sigma (St. Louis, MO), a bórsavat és az OPA reagenst a Merck (Darmstadt, D), a jódecetsav nátriumsóját és a jódazidot pedig a Fluca (Buchs, D) cégtől vásároltuk. Az acetonitrilt, a tetrahidrofuránt, az acetont, a pentánt és az etilacetátot (mind HPLC minőségű) a Rathburn cégtől (Walkerburn, UK) kaptuk.

Származékképzés. Az $\alpha$-aminosavak és az iminosavak származékképzése. A reakciót és az extrakciós lépéseket $190 \mu$ l-es mikrofiolában végeztük, melyet egy teflon membránnal ellátott csavaros tetejü üvegcsébe helyeztünk. Az automatikus mintaadagolót úgy programoztuk, hogy keverjen össze $25 \mu$ l pufferben $(0.2 \mathrm{M}$ borát puffer, $\mathrm{pH}=9.0$ ) oldott mintát $25 \mu \mathrm{l} F \mathrm{FEC}$ reagenssel ( $5 \mathrm{nM}$ acetonban) a mikrofiolában. Ezt követően a reakcióelegyet $80 \mu \mathrm{l}$ nitrogén átbuborékoltatásával jól összekevertük, majd 10 percig szobahőmérsékleten állni hagytuk. A reakció lejátszódása után $60 \mu \mathrm{l}$ extrakciós elegyet adtunk hozzá (pentán:etilacetát, 85:15), és nitrogén átbuborékoltatásával hatszor összekevertük. Ezt követően 10 percig állni hagytuk, majd az alsó fázisból tápláltunk be az enantiomerek analízisére. Minden mintabetáplálást megelőzően és követően a rendszert aceton:víz 85:15 arányú elegyével hatszor átmostuk.

63 Dungworth et al. 1973; Bada 1975.

64 HARE 1971.

65 BADA - Schroeder 1972.

66 BADA 1975.

67 BADA 1972.

68 SMith et AL. 1976. 
Az iminosavak szelektív származékképzése. A $80 \mu \mathrm{l}$ 9.5-es pH-ju 0.1M borát pufferben feloldott mintához az alábbi oldatokat adtuk hozzá: $8 \mu \mathrm{l}$ OPA reagens (50 mg OPA és $25 \mu \mathrm{l}$ merkaptoetanol $/ \mathrm{ml}$, acetonitrilben), $8 \mu \mathrm{l}$ jódacetát, ( $1 \mathrm{M}, 0.1 \mathrm{M}$ nátrium hidroxidban) és $24 \mu \mathrm{FLEC}$ reagens ( $5 \mathrm{mM}$ acetonban). Minden reagens hozzáadása után a reakcióelegyet $80 \mu$ l nitrogénnal összekevertük, és az adagolótút ötször átmostuk. A reakcióidő (beleértve az adagoló tủ átmosási idejét is) az OPA és a jódecetsav esetében 4,5 perc, a FLEC reagens esetében pedig 7 perc volt. A reakcióelegyet ezt követően $50 \mu$ dietiléter ötszöri átbuborékoltatásával extraháltuk. 10 perc várakozás után az alsó fázist injektáltuk az oszlopra.

Az enantiomerek szétválasztása és meghatározása. A kromatográfiás rendszer egy tisztító oszlopból (C18, $36 \times 4,5 \mathrm{~mm}$ belső átmérő, $20 \mu \mathrm{m}$ részecskeméretű Rsil) melyet a pumpa és a mintaadagoló közé helyeztünk, egy biztonsági oszlopból (RP- $8,15 \times 3,2 \mathrm{~mm}$ belső átmérő, $7 \mu \mathrm{m}$ részecskeméret, Brownlee) melyet a mintaadagoló és az analitikai oszlop közé kötöttük be, és az analitikai oszlopból $(300 \times 4,6 \mathrm{~mm}$ belső átmérő, 5 um részecskeméret, Kromasil oktil töltet) állt. A bakteriális tevékenység meggátlására az eluensekhez 100 mg/liter mennyiségben nátrium azidot adtunk. Az $\alpha$-aminosavak szétválasztására egy három komponensből álló gradiens rendszert alkalmaztunk, melynek összetétele az alábbi volt: A: tetrahidrofurán; B: acetát puffer (1 ml ecetsav/1 I víz, pH beállítás 7.0-re nátrium hidroxiddal); C: acetát puffer $(1,8 \mathrm{ml}$ ecetsav/1 I víz, pH beállítás 4,24ra nátrium hidroxiddal). Az áramlási sebesség $1 \mathrm{ml} /$ perc volt; a gradiens pedig az alábbiak szerint változott az idő függvényében:

\begin{tabular}{|c|c|c|c|}
\hline Idö (perc) & $\mathbf{A}(\%)$ & $\mathbf{B}(\%)$ & $\mathbf{C}(\%)$ \\
\hline 0 & 15 & 85 & 0 \\
\hline 17,0 & 16 & 84 & 0 \\
\hline 17 & 28 & 0 & 72 \\
\hline 28 & 28 & 0 & 72 \\
\hline 51,0 & 38 & 0 & 62 \\
\hline 51 & 38 & 31 & 31 \\
\hline 61 & 40 & 30 & 30 \\
\hline 75 & 44 & 28 & 28 \\
\hline 82 & 44 & 28 & 28 \\
\hline 90,0 & 46 & 27 & 27 \\
\hline 90 & 55 & 45 & 0 \\
\hline 95,0 & 55 & 45 & 0 \\
\hline 95 & 15 & 85 & 0 \\
\hline
\end{tabular}

Az iminosavak szétválasztására és meghatározására ugyanazt az analitikai oszlopot alkalmaztuk, mint az $\alpha$-aminosavak esetében. Az acetonitril és a $0.1 \mathrm{M}$ foszforsav elegyet használtuk mind a FMOC származékok (acetonitril:foszforsav, 39:61), mind a FLEC származékok (44:56) elválasztásánál. Az áramlási sebesség 1,5 ml/ perc volt.

Az aminosav enantiomerek szétválasztása és meghatározása o-ftálaldehiddel és 2,3,4,6-tetra-O-acetil-1-tio- $\beta$ glükopiranoziddal történő származékképzés után

Készülék. Az előző pontban leírtaknak megfelelő.

Vegyszerek. Az acetonitrilt, a metanolt és a tetrahidrofuránt a Rathburn (Walkerburn, U.K.) cégtől, az aminosav standardokat, az o-ftálaldehidet (OPA) és a 2,3,4,6-tetra-O-acetil-1-tio- $\beta$-glükopiranozidot (TATG) a Sigmától (St. Louis, Mo) vásároltuk. Az elúciós puffereket mono- és dinátrium-hidrogén-foszfátból állítottuk elő. A pH-t nátrium-hidroxiddal állítottuk be.

Származékképzés. A reakciót $120 \mu \mathrm{l}$-es mikroampullában végeztük, melyet 1,8 ml-es térfogatú, teflonbevonatú belső zárólappal és kupakkal ellátott ampullába helyeztünk. Az automatikus mintaadagolót úgy programoztuk, hogy a $90 \mu$ l borát pufferben $(0.4 \mathrm{M} ; \mathrm{pH}=9.5)$ oldott mintát (szabad aminosavak vagy nitrogén áramban bepá- 
rolt fehérje hidrolizátum) keverjen össze $15 \mu$ reagenssel ( $8 \mathrm{mg}$ OPA és 44 mg TATG feloldva $1 \mathrm{ml}$ metanolban). Ezt követően az oldatot $100 \mu$ l nitrogén átbuborékoltatásával jól összekevertük, majd 6 percig állni hagytuk. E reakcióelegyből - az injektáló apparátus előzetes átöblítése után - $25 \mu \mathrm{l}-\mathrm{t}$ injektáltunk az analitikai oszlopra. Az injektálást befejezve a rendszert $100 \mu$ l aceton:víz 70:30 arányú elegyével háromszor átöblítettük.

Az enantiomerek szétválasztása és meghatározása. Az enantiomerek szétválasztását fordított fázisú ( $250 \times 4.6 \mathrm{~mm}$ belső átmérő, $5 \mu \mathrm{m}$ részecskeméret, Kromasil oktil (C8) töltet) kromatográfiával végeztük. Az oszlop élettartamának megnövelésére a mintaadagoló és az analitikai oszlop közé egy biztonsági oszlopot (RP8, Newguard, $25 \times 3.2 \mathrm{~mm}$ belső átmérő, $7 \mu \mathrm{m}$ részecskeméret, Brownlee), a pumpa és a mintaadagoló közé pedig egy tisztítóoszlopot (C18, 36×4.5 mm belső átmérő, $20 \mu \mathrm{m}$ részecskeméretű Rsil) csatlakoztattunk. Az enantiomerek szétválasztására egy két komponensből álló gradiens rendszert alkalmaztunk, melynek összetétele az alábbi volt: $A=40 \%$ metanol foszfát pufferben ( $9.5 \mathrm{mM}, \mathrm{pH}=7.05) ; \mathrm{B}=$ acetonitril. Az áramlás sebessége $1 \mathrm{ml} /$ perc volt; a gradiens pedig az alábbiak szerint változott az idő függvényében:

\begin{tabular}{|c|c|c|}
\hline Idö (perc) & $\mathbf{A ( \% )}$ & $\mathbf{B}(\%)$ \\
\hline 0 & 95 & 5 \\
\hline 10 & 95 & 5 \\
\hline 35 & 83 & 17 \\
\hline 55 & 72 & 28 \\
\hline 56 & 67 & 33 \\
\hline 74 & 67 & 33 \\
\hline 75 & 62 & 38 \\
\hline
\end{tabular}

\section{A FLEC és az OPA/TATG módszer összehasonlítása}

Összehasonlítva az 1-(9-fluorenil)etil kloroformátos (FLEC) és az o-ftálaldehid/2,3,4,6-tetra-O-acetil-1-tio-ßglükopiranozidos (OPA/TATG) módszert aminosav enantiomerek szétválasztására és meghatározására - anélkül hogy a két módszer között rangsorolni akarnánk - az alábbiakat lehet elmondani:

- Mindkét módszer kiválóan alkalmas az aminosav enantiomerek szétválasztására és meghatározására, mert a származékképzés során egyiknél sem tapasztalható számottevő racemizáció.

- A FLEC módszer talán előnyösebb akkor, ha megfelelően nagy mintamennyiség áll rendelkezésünkre, és nem különösebben érdekelnek bennünket az aszparaginsav enantiomerjei. Az OPA/TATG módszerrel az aszparaginsav enantiomerjei tökéletesen szétválaszthatók.

- Az OPA/TATG módszer előnyösebb akkor, ha igen kis anyagmennyiségek állnak rendelkezésünkre (pl. kevesebb, mint 1 mg kis fehérjetartalmú mikrofosszília), vagy a minta sok ásványi anyagot tartalmaz.

- A FLEC módszer igen nagy előnye, hogy alkalmas az iminosavak szelektív származékképzésére, a (+)FLEC és (-)FLEC alkalmazásával pedig - a megváltozott elúciós sorrendet kihasználva - a csúcsok azonosításának biztonsága megnő, illetve a mintában elő sem forduló enantiomer retenciós idejét is meg lehet határozni.

- Végső összegzésként tehát elmondható, hogy mindig az analizálni kívánt anyaghoz kell a módszert igazítani, és az analizálandó mintáról kapott információk alapján kell a módszer felöl dönteni.

\section{A hagyományos és a magas hőmérsékleten végzett fehérje hidrolizis hatása az aminosavak racemizációjára}

Tanulmányozva az aminosavak racemizációját tiszta fehérjék, a tejpor és a szabad aminosavak hagyományos módon végzett hidrolízis körülményei között $\left(6 \mathrm{M} \mathrm{HCl}, 110^{\circ} \mathrm{C}, 24 \mathrm{~h}\right)$ és magas hőmérsékleten rövid ideig tartó hidrolízis időt alkalmazva a következőket lehet megállapítani:

- A szabad aminosavak racemizációja lényegesen lassúbb a peptidláncban kötött aminosavakhoz viszonyítva. Ugyanolyan körülmények között a szabad aminosavaknál előforduló racemizáció csak mintegy 20-40\%-a a peptidkötésben lévőkhöz képest.

- Hagyományos módszerrel végezve a fehérje hidrolízisét másfél, két és félszer nagyobb a racemizáció, mint magas hőmérsékleten $\left(160-180^{\circ} \mathrm{C}\right)$ a fehérje tökéletes hidrolízisét eredményező körülmények után. Ez a lényegesen alacsonyabb racemizáció magyarázható azzal, hogy magas hőmérsékleten a fehérje gyorsabban hidrolizál szabad aminosavakra, és a szabad aminosavak racemizációja lényegesen lassúbb, mint a fehérjeláncban kötötteké. Alacsony hőmérsékleten hosszabb ideig végzett hidrolízisnél a peptidláncban kötött aminosavakat hosszabb ideig érik a racemizációt kiváltó hatások, tehát minden olyan hatás, amely meggyorsítja a hidrolízist, csökkenti a racemizációt. 
- 48 óra alatt $110^{\circ} \mathrm{C}$-on $4 \mathrm{M}$ bárium-hidroxid hatására az összes aminosav (szabad vagy peptidláncban kötött) teljes mértékben racemizálódott. Bárium-hidroxidos fehérje hidrolízissel tehát a triptofán racemizációját nem lehet meghatározni.

- A magas hőmérsékleten rövid ideig tartó hidrolízist ( $160{ }^{\circ} \mathrm{C}$-on 60 és 90 perc, $170{ }^{\circ} \mathrm{C}$-on $45-60$ perc és $180^{\circ} \mathrm{C}$-on 30 perc) javasoljuk mindazoknak, akik nem akarnak enzimes hidrolízist alkalmazni, és szeretnék a fehérjeláncban bekövetkezett racemizáció mértékét meghatározni.

\section{Fehérjetartalmú régészeti leletek korának meghatározása az aminosavak racemizációja alapján}

\section{Anyagok és módszerek}

A laboratóriumba beérkező csontmintából tisztítással és mosással távolíthatók el a föld, talaj és egyéb szennyeződések. Ezt követi a szobahőmérsékleten való szárítás, őrlés majd homogenizálás. A mintát 0,1 mólos sósavval szuszpendáljuk, és a fehérje bomlásából keletkezett aminosavakat kioldjuk a mintából. Szűrés után a szabad aminosav tartalmú frakciót hűtőszekrényben tároljuk, a fehérjét tartalmazó szürési maradékot megszárítjuk, majd ismételten homogenizáljuk. A nyersfehérje tartalmat Kjel-Foss 16.200 típusú gyorsnitrogén elemzővel határozzuk meg, majd a fehérjét $6 \mathrm{M}$ sósavval hidrolizáljuk. A hidrolízis befejeztével a sósavat liofilezéssel eltávolítjuk a mintából, majd a vizes feloldás során kivált szilikátokat centrifugálással választjuk el a szabad aminosav tartalmú folyadéktól. Az oldat $\mathrm{pH}$-ját tömény nátrium-hidroxiddal $\mathrm{pH}=9$-re állítjuk be, majd a kivált kalcium és magnézium valamint nehézfémsó-hidroxidokat szűréssel vagy ismételt centrifugálással különítjük el a szabad aminosavaktól. A hidroxidok eltávolítása után a pH-t azonnal 6 és 7 közé állítjuk be, majd az így kapott oldatot szárazra pároljuk liofilezéssel. A kapott anyag már készen áll a D- és L-aminosavak, valamint az izoleucin és a D-allo-izoleucin meghatározására. Az izoleucin és a D-allo-izoleucin meghatározása LKB-4101-es típusú automatikus aminosav analizátorral történt.

Az aminosavak D- és L-változatainak meghatározása történhet nagyhatékonyságú folyadékkromatográfiával és ioncserés oszlopkromatográfiával diasztereomer dipeptid formában. Kísérleteink kezdetekor az általunk kidolgozott ioncserés oszlopkromatográfiás módszert alkalmaztuk a D- és L-aminosavak diasztereomer dipeptid alakban történő elválasztására. E módszerrel a D- és L-aminosavak szétválasztása és meghatározása az alábbi lépéseket tartalmazza:

-a minta előkészítése;

-a mintában lévő fehérje sósavas hidrolízise;

-az aminosavak szétválasztása ioncserés oszlopkromatográfiával;

-a diasztereomer dipeptidek szintézise;

-a diasztereomer dipeptidek szétválasztása és meghatározása.

A módszer leglényegesebb pontja a diasztereomer dipeptidek szintézise és szétválasztása. A védőcsoport (tercier-butil-oxi-karbonil-csoport, BOC) és az aktív észter, (N-hidroxi-szukcinimid, ONSU) kiválasztása után annak eldöntése következett, hogy melyik legyen az acilező aminosav a rendelkezésre álló fehérjeépítő aminosavak közül. Mivel szükségszerü, hogy az acilező aminosav aszimmetria centrummal rendelkezzen, valamint a kapcsolás a lehető legrövidebb időt vegye igénybe, a választás az alaninra (Ala) esett. Szintetizáltuk a tercier-butil-oxi-karbonil-L-alanin-N-hidroxi-szukcinimid aktív észtert, mely segítségével alanil diasztereomer dipeptideket hoztunk létre. A dipeptidek szétválasztására végzett kísérletekből kiderült, hogy azok még az aszparaginsav esetében is az Ala után jelennek meg a kromatogrammon, tehát az elválasztás legalább 1-1,5 órát vesz igénybe.

Fentiek miatt szintetizáltuk a bis-tercier-butil-oxi-karbonil-L-cisztin-bis-N-hidroxi-szukcinimid észtert remélve azt, hogy az ezzel létrehozott 2-szulfonsav alanil diasztereomer dipeptideket a semleges, illetve bázikus aminosavaknál gyorsabban lehet meghatározni. Az aktív észterek szintézise után kristályos aminosavakból, illetve az aminosav analizátoron elválasztott egyes aminosavakból előállítottuk a diasztereomer dipeptideket, majd szétválasztottuk őket az LKB-4101-es típusú automatikus aminosav analizátorral. Mindkét diasztereomer dipeptid formában történő elválasztási módszer alkalmas a legalább 1\%-ban jelenlévő D- (vagy L) aminosav kimutatására a 99\%-ban jelen lévő L- (vagy D) aminosav mellett.

1992-1993-ban a göteborgi Chalmers University Analytical and Marine Chemistry tanszékén folytattuk vizsgálatainkat, és határoztuk meg különböző fehérjetartalmú régészeti leletek D- és L-aminosav tartalmát nagyhatékonyságú folyadékkromatográffal. Ugyanez az intézet 1994-1995-re rendelkezésünkre bocsájtott egy folyadékkromatográfot, mellyel elkezdett vizsgálatainkat be tudtuk fejezni. Természetesen összehasonlító vizsgálatokat végeztünk az ioncserés oszlopkromatográfás és a nagyhatékonyságú folyadékkromatográfiás módszer között. Három különböző korú csontminta esetében (a kort radiokarbon módszerrel határozták meg) kapott vizsgálataink eredményeit az 5. táblázat tartalmazza.

A táblázat adataiból látható, hogy a két módszer között az azonosság megfelelö, tehát a két módszerrel kapott eredményeket együtt lehet értékelni a csont korának meghatározására létrehozott hitelesítő görbék szerkesztésekor. Mivel a HPLC módszer sokkal könnyebben kivitelezhetó, mint az IEC-s, ezért amennyiben egy 
HPLC rendelkezésre áll, mindenképpen azt kell alkalmazni. Ezért mi is vizsgálataink nagyobb részét az előző fejezetben leírt HPLC-módszerekkel végeztük, azok közül is előnyben részesítettük az OPA/TATG módszert. Amennyiben azonban nem áll rendelkezésre folyadékkromatográf, vagy szabad kapacitás mutatkozik az aminosav analizátoron, az IEC módszer (ilyen esetben) előnyösen alkalmazható.

\begin{tabular}{|c|c|c|c|c|c|c|}
\hline \multirow{2}{*}{$\begin{array}{l}\text { A minta } \\
\text { kora (év) }\end{array}$} & \multirow{2}{*}{$\begin{array}{l}\text { Analitikai } \\
\text { módszer }\end{array}$} & \multicolumn{5}{|c|}{ A D/L arányok a különböző aminosavakra } \\
\hline & & Phe & Asp & Ala & Ile & Val \\
\hline \multirow{2}{*}{ 1. 15.600} & IEC & 0,6 & 0,4 & 0,2 & - & - \\
\hline & HPLC & 0,6 & 0,4 & 0,2 & - & - \\
\hline \multirow{2}{*}{ 2. 38.450} & IEC & - & - & 0,4 & 0,1 & - \\
\hline & HPLC & - & - & 0,4 & 0,1 & - \\
\hline \multirow[t]{2}{*}{3.46 .900} & IEC & - & - & 0,5 & 0,1 & - \\
\hline & HPLC & - & - & 0,5 & 0,1 & - \\
\hline
\end{tabular}

5. táblázat. Az ioncserés oszlopkromatográfiás (IEC) és nagyhatékonyságú folyadékkromatográfiás (HPLC) módszerrel eltérő korú csontmintákból meghatározott D/L arányok különböző aminosavakra

\section{Eredmények}

Hitelesítő görbe a kormeghatározáshoz

Az analitikai módszerek kiválasztása és kidolgozása, valamint a felmerülő hibák korrigálása után lehetett hozzáfogni a különböző régészeti leletek korának meghatározásához. Az aminosavak racemizációján alapuló módszernél különös tekintettel kell lenni a hőmérsékletre, azokra a hőmérsékleti viszonyokra, melyen a minta keresztülment az élő szervezet pusztulása után napjainkig. Mivel az évezredek alatt végbemenő hőmérsékleti változásokat, hőmérsékleti ingadozásokat csak közelítőleg ismerjük, csak becsülni tudjuk a racemizációs (illetve epimerizációs) folyamat során a reakció hőmérsékletét, annak pontos meghatározására (egyes szélsőséges viszonyoktól eltekintve, pl. az óceán mélye) nincs lehetőség.

E tényből kiindulva kellett megoldást keresni arra, hogy az ismeretlen minta összetételét valamilyen módon egy más kormeghatározási módszerrel megismert korú minta összetételéhez lehessen hasonlítani, ügyelve arra, hogy az ismert és az ismeretlen korú minta lehetőleg azonos vagy igen hasonló elóéletü legyen. A legfontosabb szempont itt az volt, hogy a minta milyen talajmélységből (hőmérséklet) és milyen talajtípusból $(\mathrm{pH})$ került elő, hiszen a racemizációs folyamatokat elsősorban a hőmérséklet és a pH befolyásolja.

Fentiek miatt hazánk különböző múzeumaiból összegyűjtöttünk mintegy 150 darab csontmintát, melyeknek korát előzetesen radiokarbon módszerrel meghatározták. A mintegy 150 darab, radiokarbon módszerrel már meghatározott korú csontmintából 24 analíziseinek eredményeit hat D- és L-aminosavra a 6. táblázat tartalmazza. Ez a hat aminosav felöleli azt a tartományt, amelyben az aminosavak racemizációját, illetve epimerizációját alkalmazni lehet a kormeghatározásra, hisz tartalmazza a leggyorsabban (His, Phe) és a leglassabban (lle, Val) racemizálódó aminosavakat. A többi vizsgált aminosavat az áttekinthetőség kedvéért a táblázat nem tartalmazza. 


\begin{tabular}{|c|c|c|c|c|c|c|c|}
\hline \multirow{2}{*}{$\begin{array}{l}\text { A minta kora radiokar- } \\
\text { bon módszerrel (év) }\end{array}$} & \multicolumn{7}{|c|}{ Az aminosavak D/L aránya } \\
\hline & His & Phe & Asp & Glu & Ala & Ile & Val \\
\hline 2.200 & 0,1 & - & - & - & - & - & - \\
\hline 2.800 & 0,2 & 0,1 & - & - & - & - & - \\
\hline 3.110 & 0,2 & 0,1 & - & - & - & - & - \\
\hline 3.240 & 0,2 & 0,1 & - & - & - & - & \\
\hline 4.630 & 0,3 & 0,2 & 0,1 & - & - & - & - \\
\hline 5.460 & 0,3 & 0,2 & 0,1 & - & - & - & - \\
\hline 6.850 & 0,4 & 0,3 & 0,2 & 0,1 & - & - & - \\
\hline 11.200 & 0,6 & 0,4 & 0,3 & 0,1 & 0,1 & - & - \\
\hline 12.400 & 0,7 & 0,5 & 0,3 & 0,1 & 0,1 & - & - \\
\hline 15.600 & - & 0,6 & 0,4 & 0,2 & 0,2 & - & - \\
\hline 18.600 & - & 0,7 & 0,4 & 0,2 & 0,2 & - & - \\
\hline 20.200 & - & 0,7 & 0,5 & 0,2 & 0,2 & - & - \\
\hline 22.600 & - & - & 0,5 & 0,3 & 0,2 & - & - \\
\hline 25.400 & - & - & 0,6 & 0,3 & 0,2 & - & - \\
\hline 28.600 & - & - & 0,6 & 0,3 & 0,3 & - & - \\
\hline 30.400 & - & - & 0,6 & 0,3 & 0,3 & - & - \\
\hline 32.500 & - & - & 0,7 & 0,4 & 0,3 & 0,1 & - \\
\hline 36.900 & - & - & - & 0,4 & 0,4 & 0,1 & - \\
\hline 44.600 & - & - & - & 0,5 & 0,5 & 0,1 & - \\
\hline 46.800 & - & - & - & 0,5 & 0,5 & 0,1 & - \\
\hline 54.300 & - & - & - & 0,5 & 0,5 & 0,2 & 0,1 \\
\hline 62.200 & - & - & - & 0,6 & 0,6 & 0,2 & 0,1 \\
\hline 65.000 & - & - & - & 0,6 & 0,6 & 0,2 & 0,1 \\
\hline 72.400 & - & - & - & - & 0,7 & 0,2 & 0,1 \\
\hline
\end{tabular}

Rövidítések: His = hisztidin, Phe = fenilalanin, Asp = aszparaginsav, Glu = glutaminsav, Ala $=$ alanin, Ile $=$ izoleucin, $\mathrm{Val}=$ valin. 


\begin{tabular}{|c|c|}
\hline Aminosavak & Felezési idö (év) \\
\hline Hisztidin & 5.500 \\
\hline Fenilalanin & 8.500 \\
\hline Tirozin & 8.600 \\
\hline Aszparaginsav & 13.500 \\
\hline Szerin & 16.500 \\
\hline Treonin & 17.000 \\
\hline Glutaminsav & 28.500 \\
\hline Alanin & 32.000 \\
\hline Izoleucin & 110.000 \\
\hline Leucin & 140.000 \\
\hline Valin & 180.000 \\
\hline
\end{tabular}

7. táblázat. Az aminosavak racemizációs és epimerizációs felezési ideje Magyarországról származó csontmintákban

A táblázat adatai alapján számoltuk ki a különböző aminosavak racemizációjának felezési idejét. A kapott eredményeket a 7. táblázatban foglaltuk össze. A táblázat adataiból látható, hogy a His a 2-12 ezer év, a Phe a 3-20 ezer év, az Asp az 5-35 ezer év, az Ala pedig a 10-80 ezer év közötti minták korának meghatározására alkalmazható. Izoleucinnal a 30 ezer év, valinnal pedig az 55 ezer év feletti minták kora határozható meg. 0,1nél kisebb, ill. 0,7-nél nagyobb D/L arányok a táblázatban nincsenek, mert a meghatározás pontossága ezeken a határokon túl bizonytalan.

A kalibrációs görbéket szemlélve megállapítható, hogy mindegyik görbe gyakorlatilag lineárisnak tekinthető a 0,1-0,5 D/L arány között, és ez a szakasz adja a legpontosabb eredményt a kormeghatározásra, hisz itt a D-aminosav megfelelő, jól mérhető koncentrációban van jelen. A hitelesítő görbe 0,5 után kezd el görbülni, és ez a görbület 0,6 D/L arány fölött már bizonytalanná teszi a meghatározást.

A racemizáció foka szerint az aminosavakat három csoportba lehet sorolni. Az első csoportot alkotják a gyors racemizációs idejű aminosavak: tirozin, fenilalanin és hisztidin, melyeket a fiatal (5.000-50.000 éves) csontminták korának meghatározására tudunk felhasználni. A második csoportba tartoznak azok az aminosavak, melyek a 10.000-100.000 év közötti csontmintákra használhatók. Ebbe a csoportba tartoznak az aszparaginsav, glutaminsav, treonin, szerin, alanin, metionin, lizin és arginin. A harmadik csopotot alkotó aminosavak - valin, izoleucin, leucin - az 50.000-100.000 évnél idősebb csontminták korának meghatározására alkalmasak. Mindhárom csoportnál 3-5 hitelesítő görbével rendelkezünk, így a csoporton belüli átfedéseket biztosítani tudjuk, sőt egy-egy csontmintára esetenként 2-3 hitelesítő görbe adatait is fel tudjuk használni a kor meghatározására.

\section{A hitelesítö görbe alkalmazása a kormeghatározásra}

Miután megismertük a különböző korú csontminták D/L-aminosav arányának időfüggését, a módszer alkalmassá vált a hitelesítő görbét alkotó mintákhoz hasonló körülmények közül származó ismeretlen korú csontminta korának meghatározására. A hitelesítő görbe D/L aminosav arányát hasonlítva az ismeretlen minta D/L aminosav arányához, a minta kora a hitelesítő görbéről leolvasható. Egy ismeretlen minta esetében 2-3 esetleg 4 aminosavat használunk fel a kormeghatározásra, majd végül a különböző aminosavak alapján kapott korokat átlagolva kapjuk meg az ismeretlen minta korát. Mindegyik mintára meg lehet azonban találni azt az optimális D/L arányt, amely a legjobb eredményt adja a korra. A többi aminosav segítségével meghatározott kor az optimális D/L arányból számolt eredményeket megerősítheti, vagy esetleg megkérdőjelezheti. PI. a táblázatban szereplő, radiokarbon módszerrel 11.200 évesnek meghatározott korú csontmintára a His, a Phe, az Asp és az Ala D/L arányai a következők: 0,682, 0,473, 0,271 és 0,112. Ebben az esetben a Phe és az Asp D/L arányai javasolhatók a kormeghatározásra, mert azok vannak az ideális tartományban, a hitelesítő görbe lineárisnak tekinthető részén, de a His és az Ala D/L aránya is értékes információt szolgáltathat a kort illetően. 
Természetesen elvégeztük a kapott adatok statisztikai analízisét is. A csontminta ismert korát $(Y)$ a $D / L$ arányra $\left(\mathrm{X}_{1}\right)$ ill. az $\ln [(1+\mathrm{D} / \mathrm{L}) /(1-\mathrm{D} / \mathrm{L})]\left(\mathrm{X}_{2}\right)$-re vonatkoztatva négy aminosav (Phe, Asp, Ala, lle) esetében olyan becslő egyenleteket kaptunk $(Y=a+b X)$, melyekkel a korbecslés elvégezhető. Mind a nyolc regressziós egyenletnél a determinációs koefficiens $\left(r^{2}\right)$ értéke több volt 0,99-nél. Mindegyik aminosav esetében az $r_{x 1 \times 2}$ nagyobb volt, mint 0,99 , ami annak a következménye, hogy az $X_{2}-t$ az $X_{1}$-ből számoltuk. A regresszióból számolt eltérések szórását (a becslés standard hibája: $\mathrm{s}_{\mathrm{yx}}$ ) fel lehet használni a korbecslés standard hibájának számolására.

Egy példán bemutatva a kalibrációs görbék használatát az alábbi eredményeket kaptuk:

L-His: 0,0697mg,

Kor a hitelesítő görbéről:

L-Phe: 0,0543 mg,

Kor a hitelesítő görbéről:

L-Asp: 0,1346 mg,

Kor a hitelesítő görbéről:
D-His: 0,0298

D-Phe: 0,0138

D-Asp:0,0245
D/L His : 0,428

7.100 év; S.E. $=337$.

D/L Phe :0,254

6.950 év; S.E. $=191$.

D/L Asp :0,182

6.900 év; S.E. $=465$.

Tényleges kor: a három számított kor átlaga: 6980 év. A kor S.E. értéke 202 év, és teljesen biztosak lehetünk afelöl, hogy a vizsgált minta kora 6554 és 7406 év között van.

$\mathrm{Az}$ aszparaginsav értékes információt adhat a kormeghatározást illetően, amennyiben azonban az aszparaginsavval meghatározott érték nagyon eltérő a másik két aminosav segítségével kapottól, célszerű ekkor a His és a Phe D/L arányára hagyatkozni, a kort a két aminosavból számolni, mert az Asp D/L aránya nem éri el a 0,2-t és így nem ad pontos eredményt a kormeghatározásra.

\section{Következtetések, a módszer használhatósága}

Mivel az utóbbi időben az aminosav racemizáción alapuló kormeghatározást sok kritika érte, egy olyan módszer kidolgozására vállalkoztunk, melynek segítségével az aminosav racemizáción alapuló kor pontosabbá tehető. A radiokarbon módszerrel meghatározott korú minták D- és L-aminosav tartalmát meghatározva, és a $D / L$ arányt ábrázolva a kor függvényében ún. hitelesítő görbéket szerkesztettünk. Minden korra megtalálható az a hitelesítő görbe, melynek segítségével a legjobb közelítést tudjuk adni a korra. 2-3 (esetleg 4) aminosav együttes alkalmazásával a kor pontosítható, és egymástól független mérések átlaga tekinthető a minta tényleges korának. A hitelesítő görbét alkalmazva kiküszöböljük a hőmérséklet és a pH okozta hibaforrásokat, viszont így a módszert egy másik kormeghatározási módszer esetleges hibájával terheljük. Az aminosav racemizáción alapuló kormeghatározási módszer természetesen abszolúttá válik akkor, ha becsüljük a hőmérsékleti viszonyokat, ebben az esetben ugyanis csak a mintában lévő $D / L$ aminosav arány az ismeretlen, az összes többi adat, így a minta kora is a reakciósebességi egyenletből számítható.

Módszerünket sikerrel alkalmaztuk Magyarországról származó csontminták esetén. A radiokarbon módszerrel és a kalibrációs görbéinkkel meghatározott korok közti különbség elhanyagolható volt. Minden esetben nagyon óvatosan jártunk el mind a minta előkészítésnél, mind a hitelesítő görbe alkalmazásánál; ügyeltünk arra, hogy az ismeretlen minta eredete hasonló legyen ahhoz, mint amikből a hitelesítő görbét megszerkesztettük, valamint vigyáztunk arra, hogy az előkészítés lépései is teljesen hasonlóak legyenek. Tisztában vagyunk a módszer gyenge pontjaival, és azzal, hogy a módszer terhelt a radiokarbon módszer hibájával. Eredményeink mégis bizonyítják a módszer használhatóságát, megbízhatóságát. Módszerünket csak nagyon óvatosan és fenntartással javasoljuk alkalmazni más környezeti körülmények között (hőmérséklet, pH, talajösszetétel), hisz ott mások a racemizációs viszonyok. Javasoljuk azonban, hogy eredményeinkre alapozva dolgozzon ki mindenki a saját környezetének megfelelő kalibrációs görbéket, ha az aminosav racemizáción alapuló kormeghatározást egyrészt alkalmazni akarja, másrészt pontosabbá akarja tenni.

\section{Összefoglalás}

A fehérjék aminosav tartalma (D-aminosav is) meghatározásának legfontosabb lépése a fehérjék hidrolízise. A meghatározás során minden olyan lépést kerülni kell, ahol jelentős mértékű racemizáció léphet fel, mert az a D-aminosavak mennyiségét meghamisítaná. Ezért a hagyományos módszerekhez képest egy új, rövid ideig magas hőmérsékleten végzett hidrolízis módszert dolgoztunk ki egyrészt a racemizáció lehető legkisebb szintre szorítása, másrészt az oxidációra érzékeny aminosavak pontos meghatározása érdekében. A módszer lényege a $170^{\circ} \mathrm{C}$-on 30 percig $6 \mathrm{M}$ sósavval végzett hidrolízis, mely a fehérjét minimális racemizációval hidrolizálja aminosavakra. 
Ezt követően két módszert hasonlítottunk össze az $\alpha$-aminosav enantiomerek szétválasztására és meghatározására. Az első módszer szerint o-ftálaldehiddel (OPA) és az optikailag aktiv 2,3,4,6-tetra-O-acetil-1-tio-ßglükopiranoziddal történő származékképzés után fordított fázisú folyadékkromatográfiával határoztuk meg a D-aminosavakat. A származékképzés során a reakció szobahőmérsékleten, néhány perc alatt lejátszódik, és a kapott származékok igen stabilak. A képzett diasztereoizomerek szelektivitása - a lizin és az ornitin kivételével - különösen jónak mondható. A származékok fluoreszcenciás gerjesztési és emissziós maximuma 342 és 410 $\mathrm{nm}$ volt. A kimutathatóság határa fluoreszcens detektor esetén 2 pmol, elektrokémiai detektor esetén pedig 1 pmol volt az aminosavak többségére.

Ezután kipróbáltuk az $\alpha$-aminosav enantiomerek szétválasztására és meghatározására, valamint az iminosavak szelektív meghatározására az 1-(9-fluorenil)etil kloroformáttal történő származékképzés után kapott származékokat fordított fázisú kromatográfiával. Rendkívüli előnye az alkalmazott eljárásnak az, hogy a reagens mindkét enantiomerjének (+FLEC és -FLEC) használatával megnő a csúcsok azonosításának megbízhatósága, mivel a reagens másik enantiomerjével végezve el a származékképzést, megváltozik a diasztereomer származékok elúciós sorrendje. A D- és az L-hidroxiprolin cisz- és transz módosulatát a módszerrel tökéletesen el lehet választani egymástól.

Mindkét módszer segítségével meghatároztuk a szabad aminosavak valamint a fehérjék racemizációját a folyadék- és gázfázisú hidrolízis során, valamint elvégeztük néhány ismert korú csontminta D- és L-aminosav tartalmának meghatározását.

Miután kidolgoztuk az igen alacsony szintű racemizációt okozó fehérjehidrolízis módszerünket, hazánk különböző intézményeiből összegyűjtöttünk mintegy 100 darab fosszilis csontmintát, melyek korát korábban a Debreceni ATOMKI-ban radiokarbon módszerrel meghatározták. Meghatároztuk ezen minták D- és L-aminosav tartalmát származékképzés után fordított fázisú folyadékkromatográfiával. Ezt követően a D- és L-aminosav mennyiségéből meghatároztuk a D/L arányokat, melyeket ábrázolva az idő függvényében un. kalibrációs görbéket szerkesztettünk. Ezután a kalibrációs görbéket használtuk ismeretlen csontminta korának meghatározására, miután meghatároztuk annak D- és L-aminosav tartalmát. Mivel az aminosavak racemizációját nemcsak az élő szervezet halála után eltelt idő, hanem a talaj hőmérséklete, pH-ja, nyomelemtartalma és egyéb más körülmények is befolyásolják, a radiokarbon keltezésre, mint abszolút módszerre történő kalibrálással a környezet okozta racemizációs hibákat ki tudtuk küszöbölni.

A D- és az L-aminosavak analízise után kitűnt, hogy a kormeghatározásra leginkább az alábbi aminosavak alkalmasak, mert egyrészt nagyobb mennyiségben fordulnak elő még a 100.000 évnél idősebb csontokban is, másrészt pedig viszonylag könnyű őket HPLC-vel meghatározni: hisztidin, fenilalanin, aszparaginsav, glutaminsav, alanin, izoleucin és valin. Vizsgálataink során meghatároztuk ezen aminosavak racemizációs felezési idejét, és ettől függően a kormeghatározás szempontjából az aminosavakat különböző csoportokba tudtuk osztani. A hisztidin a fenilalanin és az aszparaginsav alkalmas az ún. fiatalabb minták korának becslésére (2-35.000 év), a glutaminsav és az alanin a 10-80.000 év közötti mintákra, míg az izoleucinnal és a valinnal a 30.000-450.000 év közötti minták kora becsülhető.

Elemeztük a kidolgozott módszer pontosságát is. Megállapítottuk, hogy 6-10.000 év közötti mintáknál egy aminosav használata esetén a módszer pontossága $\pm 500-600$ év, több aminosav használata esetén pedig $\pm 200-300$ év. 


\title{
New method for the age determination of fossilized bones based on amino acid racemization
}

\begin{abstract}
JÁNOS CSAPÓ
When using to traditional protein hydrolysis, racemization was $1,2-1,6$ times as high as that obtained at high temperatures $\left(160-180^{\circ} \mathrm{C}\right)$, under conditions ensuring total hydrolysis of the protein. This lower degree of racemization may be explained by the fact that, at high temperatures, the protein hydrolyses more rapidly into free amino acids and the racemization of free amino acids is considerably slower that of amino acids bound in polypeptides. Therefore high temperature hydrolysis (at $160{ }^{\circ} \mathrm{C}$ for 45 to 60 minutes, at $170{ }^{\circ} \mathrm{C}$ for $30-45$ minutes and $180^{\circ} \mathrm{C}$ for 30 minutes) are recommended for those who would like to hydrolyse the protein for short times and to determine the degree of racemization occurring in the polypeptide chain, but do not wish to use enzyme hydrolysis.

After developing protein hydrolysis method with low racemization, a method has been developed to determine the age of fossil bone samples based on amino acid racemization (AAR). Approximately one hundred fossil bone samples of known age from Hungary were collected and analysed for D- and L-amino acids. As the racemization of amino acids is affected by temperature, $\mathrm{pH}$, metal content of the soil, and time passed since death, these factors were eliminated by comparing the estimated age to age determined by the radiocarbon method. Determining the D- and L- amino acid contents in samples of known age, determining the half life of racemization, and plotting the $\mathrm{D} / \mathrm{L}$ ratio as a function of time, calibration curves were obtained. These curves can be used for the age estimation of samples after determining their D- and L- amino acid content. The D/L ratio for 2 to 3 amino acids was determined for each sample and the mean value of estimated ages based on calibration curves was considered to estimate age of the fossil samples.
\end{abstract}




\section{Irodalom}

Abelson 1954 Abelson, Philip H.: Amino acids in fossils. Carnegie Institute of Washington Year Book 53. 97-108.

ALDAG - Young - YAMAMOTo 1971 Aldag, Rudolf W. - Young, J. L. - Yamamoto, M.: Determination of D- and L-amino acids by enzymatic reactions. Phytochemistry 10. 267-274.

AswAD 1984 Aswad, Dana W.: Determination of D- and L-aspartate in amino acid mixtures by high performance liquid chromatography after derivatization with chiral adduct of o-phthalaldehyde. Analytical Biochemistry 137. 405.

BADA 1971 Bada, Jeffrey L.: Kinetics of the Nonbiological Decomposition and Racemization of Amino Acids in Natural Waters. In: Hem, John D. (ed.): Non-equilibrium systems in natural water chemistry. Chemistry Series 106. 309-331.

BADA 1972a Bada, Jeffrey L.: The dating of fossil bones using the racemization of isoleucine. Earth and Planetary Science Letters 15. 223-231.

BADA 1972b Bada, Jeffrey L.: Kinetics of racemization of amino acids as a function of $\mathrm{pH}$. Journal of the American Chemical Society 94. 1371-1373.

BADA 1975 Bada, Jeffrey L.: Amino acid racemization reactions and their geochemical implications. Naturwissenschaften 62. 71-79.

BADA - LuYENDYK - MAYNARD 1970 Bada, Jeffrey L. - Luyendyk, Bruce P. - Maynard, J. Barry: Marine sediments: Dating by the racemization of amino acids. Science 70. 730-736.

BADA - Schroeder 1972 Bada, Jeffrey L. - Schroeder, Roy A.: Racemization of isoleucine in calcareous marine sediments: Kinetics and mechanism. Earth and Planetary Science Letters 15. 1-12.

BadA - Kvenvolden - Peterson 1973: Bada, Jeffrey L - Kvenvolden, Keith A. - Peterson, Etta.: Concordance of collagen based radiocarbon and aspartic-acid racemization ages. Nature 245. 308-315.

BadA - Protsch 1973 Bada, Jeffrey L. - Protsch, Reiner: Racemization reaction of aspartic acid and its use in dating fossil bones. Proceedings of the National Academy of Sciences of the USA 70. 1331-1334.

BETNER - FöLDI 1988 Betner, Ingvar - Földi, P.: The FMOC-ADAM approach to amino acid analysis. LC. GC. 6. 832.

BodAnszky - ConkLIN 1967 Bodanszky, Miklós - Conklin, Lois E.: A simple method for the study of racemization in peptide synthesis. Chemical Communications 556. 773-774.

BuCK - KRUMmen 1987 Buck, Robert Helmut - Krummen, Kurt: High-performance liquid chromatography determination of enantiomeric amino acids and amino alcohols after derivatization with o-phthalaldehyde and various chiral mercaptans. Journal of Chromatography 387. 255.

CHARLES - FISHER - GIL-Av 1963 Charles, Rosita - Fisher, Gabriella - Gil-Av, Emanuel, Israel Journal of Chemistry 1. 234.

Charles et Al. 1975 Charles, Rosita - Beitler, Uzi - Feibush, Binyamin - Gil-Av, Emanuel: Separation of optical isomers of amino acids with packed columns. Supelco Inc. Bellefonte. GC. Bulletin 765.

Chen et Al. 1987 Chen, Shui Tein - Chiou, Shyh Horng - Chu, Yen Ho - Wang, Kung Tsung: Rapid hydrolysis of proteins and peptides by means of microwave technology and its application to amino acid analysis. International Journal of Peptide and Protein Research 30/4. 572-576.

CHEN - Wu - WANG 1989 Chen, Shui Tein - Wu, Shih Hsiung - Wang, Kung Tsung: Rapid racemization of optically active amino acids by microwave oven-based heathing treatment. Chemical Biology \& Drug Design 33/1. 73-75

CHIOU - WANG 1988 Chiou, Shyh Horng - Wang, Kung Tsung: Simplified protein hydrolysis with methanesulphonic acid at elevated temperature for the complete amino acid analysis of proteins. Journal of Chromatography 448/3. 404-410.

Cronin - Pizzarello 1983 Cronin, John R. - Pizzarello, Sandra: Amino acids in meteorites. Advances in Space Research 3. 5.

Cunico ET AL. 1986 Cunico, R. - Majer, A. G. - Wehr, C. T. - Sheehan, T. L.: High sensitivity amino acid analysis using a novel automated precolumn derivatization system. Biochromatography 1.6-14

CsaPó - Tóth-Pósfal - Csapó-Kiss 1990 Csapó, János - Tóth-Pósfai, Ilona - Csapó-Kiss, Zsuzsanna: Separation of D- and L-amino acids by ion exchange column chromatography in the form of 2-sulfonilic acid alanyl dipeptides. In: Lubec, G. Rosenthal, G. A. (ed.): Amino Acids. Chemistry, Biology and Medicine. ESCOM Sci. Publ. B.V. 96.

CSAPó ET AL. 1990 Csapó, János - Csapó-Kiss, Zsuzsanna - Költő, László - Papp, Ildikó: Age determination of fossil bone samples based on the ratio of amino acid racemization. In: Archaeometry '90. Basel, 1990. 627.

CSAPó - Tóth-Pósfal - CSAPó-Kıss 1991 Csapó, János - Tóth-Pósfai, Ilona - Csapó-Kiss, Zsuzsanna: Separation of D- and L-amino acids by ion exchange column chromatography in the form of alanyl dipeptides. Amino Acids 1. 331. 


\section{AZ AMINOSAVAK RACEMIZÁCIÓJA ALAPJÁN}

CSAPó et Al. 1994 Csapó, János - Csapó-Kiss, Zsuzsanna - Némethy, Sándor - Folestad, Staffan - Tivesten, A. - Martin T. G.: Age determination based on amino acid racemization: A new posibility. Amino Acids 7. 317-325.

D'ANIELlo - GiuditTA 1980 D'aniello, Antimo - Giuditta, Antonio: Presence of D-alanine in crustacean muscle and hepatopancreas. Comparative Biochemistry and Physiology Part B: Biochemistry and Molecular Biology 66. 319-322.

DUNGWORTH - VINCKEN - SCHWARTZ 1974 Dungworth, Graham - Vincken, N. J. - Schwartz, Alan W. In: Tissot, B. - Bienner, F. (eds.): Advances in organic geochemistry 1973. Paris, 1974. 689.

DUNGWORTH - VRENKEN - SchWARTZ 1977 Dungworth, Graham - Vrenken, J. A. T. - Schwartz, Alan W.: Amino acid composition of pleistocene collagene. Comparative Biochemistry and Physiology 51/3. 331-335.

EINARSSON - JOSEFSSON - LAGERKVIST 1983 Einarsson, Stefan - Josefsson, Bjoern - Lagerkvist, Soeren: Determination of amino acids with 9-fluorenylmethyl chloroformate and reversed-phase high performance liquid chromatography. Journal of Chromatography 282. 609.

EINARSSON 1985 Einarsson, Stefán: Selective determination of secondary amino acids using precolumn derivatization with 9-fluorenylmethyl chloroformate and reversed-phase high performance liquid chromatography. Journal of Chromatography 348. 213.

EINARSSON ET AL. 1987 Einarsson, Stefán - Josefsson, Bjoern - Möller, Per. - Sanchez, Domingo: Separation of amino acid enantiomers and chiral amines using precolumn derivatization with (+)-1-(9-fluorenyl)ethyl chloroformate and reversed-phase liquid chromatography. Analytical Chemistry 59. 1191.

EINARSSON - FolestAD - JosefsSON 1987 Einarsson, Stefán - Folestad, Staffan - Josefsson, Bjoern: Separation of amino acid enantiomers using precolumn derivatization with o-phthalaldehyde and 2,3,4,6,-tetra-O-acetyl-1-thio- $\beta$ glucopyranoside. Journal of Liquid Cromatography 10. 1589.

FrANK ET AL. 1981 Frank, Hartmut - Woiwode, Wolfgang - Nicholson, Graeme - Bayer, Ernst: Determination of the rate of acidic catalysed racemization of protein amino acids. Liebigs Annale der Chemie 1981/3. 354-365.

GIL-Av - FEIBUSH - ChARLEs 1966 Gil-Av, Emanuel - Feibush, Binyamin - Charles, Rosita: Separation of optical isomer amino acids with packed columns. Supelco Inc. Bellefonte. GC Bulletin 765

GILMAN - WOODWARD 1990 Gilman, Lee B. - Woodward, Cliff: An evaluation of microwave heating for the hydrolysis of proteins. In: Villafranca, J. J. (ed.): Current Research in Protein Chemistry, Vol. 3. San Diego, CA, 1990. 23-26.

GoldHABER - BRodzins - SUNYAR 1957 Goldhaber, Maurice - Grodzins, Lee - Sunyar, Andrew W.: Evidence for circular polarization of bremsstrahlung produced by beta rays. Physical Review Journals Archive 106. 826.

GüBITZ - JuffmAnn - Jellenz 1982 Gübitz, G. - Juffmann, F. - Jellenz, W.: Direct separation of amino enantiomers by high performance ligand exchange chromatography on chemically bonded chiral phases. Chromatographia 16. 103-106.

GüBITZ - MiheLlyes1984 GüBITZ, G. - Minelyyes, S.: Direct separation of 2-hydroxy acid enantiomers by high-performance liquid chromatography on chemically bonded chiral phases. Chromatographia 19. 257-259.

HARE 1969 Hare, Peter E.: Geochemistry of proteins, peptides and amino acids. In: Eglington, Geoffrey - Murphy, Mary T. J. (eds.): Organic geochemistry, methods and results. New York, 1969. 438-462.

HARE 1971 Hare, Peter E.: Effect of hydrolysis on the racemization rate of amino acids. Carnegie Institute of Washington Year Book 70. 256-261.

Hare - Abelson 1967 Hare, Peter E. - Abelson, Philip H.: Racemization of amino acids in fossil shells. Carnegie Institute of Washington Year Book 66. 526-536.

Hare - Mitterer 1968 Hare, Peter E. - Mitterer, Richard M.: Laboratory simulation of amino acid diagenesis in fossils. Carnegie Institute of Washington Year Book 67. 205-212.

HARE - HörING 1973 Hare, Peter E. - Hoering, Thomas C.: Separation of amino acid optical isomers by gas chromatography. Carnegie Institute of Washington Yearbook 72. 1138-1144.

HelfmAn - BADA 1975 Helfman, Patricia Masters - Bada, Jeffrey L.: Aspartic acid racemization in tooth enamel from living humans. Proceedings of the National Academy of Sciences of the USA 72. 2891-2895.

HelfmAn - BADA 1976 Helfman, Patricia Masters - Bada, Jeffrey L.: Aspartic acid racemization in tooth enamel from living humans. Nature 262. 279-284.

KARAGUNIS - DRIKos 1984 Karagunis, Georg - Drikos, G: Zur Stereochemie der freien Triarylmethylradikale. Zeitschrift für Physikalische Chemie (B) 26. 428-438.

KNABE 1984 Knabe, J. In: A chiral column for control of optical purity by HPLC based on ligand exchange. Macherey-Nagel Gmbh and Co. Nucleosil Chiral-1. 1986. West Germay 
Kvenvolden - Lawless - Ponanperuma 1970 Kvenvolden, Keith A. - Lawless, James G. - Ponnamperuma, Cyril: Nonprotein Amino Acids in the Murchison Meteorite. Proceedings of the National Academy of Sciences of the USA 68. 486-490.

LIARDON - LEDERMAN 1986 Liardon, Remy - Ledermann, Simone: Effect of peptide bind cleavage on the racemization of amino acid residues in proteins. Journal of Agricultural and Food Chemistry 34. 557-563.

LIARDON - FRIEDMAN 1987 Liardon, Remy - Friedman, Mendel: Effect of peptide bind cleavage on the racemization of amino acid residues in proteins. Journal of Agricultural and Food Chemistry 35. 661-667.

LINDROTH - MopPER 1979 Lindroth, Peter - Mopper, Kenneth: High performance liquid chromatographic determination of subpicomole amounts of amino acids by precolumn fluorescence derivatization with o-phthalaldehyde. Analytical Chemistry 51. 1667.

MANNING 1970a Manning, James M. 1970. In: Williams - Smith 1977.

MANNING 1970b Manning, James M.: Determination of D- and L-amino acid residues in peptides. Use of tritiated hydrochloric acid to correct for racemization during acid hydrolysis. Journal of American Chemical Society 92. 7449-7454.

MANNING - Moore 1968 Manning, James M. - Moore, Stanford: Determination of D- and L-amino acids by ion exchange column chromatography as L-D and L-L dipeptides. Journal of Biological Chemistry 243. 5591-5597.

MARFEY 1984 Marfey, Peter: Determination of D-amino acids. II. Use of bifunctional reagent 1,5-difluoro-2,4-dinitrobenzene. Carlsberg Research Communications 49. 591-596.

NAKAPARSKIN et AL. 1970 Nakaparskin, S. - Birrell, P. - Gil-Av, Emanuel - Oro, Joan: Gas Chromatography With Optically Active Stationary Phases: Resolution of Amino Acids. Journal of Chromatography Science 8/4. 177-182.

Neuberger 1948 Neuberger, Albert: Stereochemistry of amino acids. Advances in Protein Chemistry 4. 297-383.

PASTEUR 1860 Pasteur, Louis 1860. In: Second lecture delivered before the Chemical Society of Paris. In: Richardson, G. M. (ed.): The Foundations of Stereo Chemistry. New York, 1901.

PETIT 1974 Petit, Michael G.: Racemization rate constant for protein-bound aspartic acid in woodrat middens. Quaternary Research 4. 340-345.

PICKERING - Newton 1992 Pickering, Michael V. - Newton, Paul: Amino acid hydrolysis: Old problems, new solutions. LC-GC. 8/10. 778-781.

Pollock - OYAmA - Johnson 1965 Pollock, Glenn E. - Oyama, Vance I. - Johnson, R. D.: Resolution of racemic amino acids by gas chromatography. Journal of Gas Chromatography 3. 174-176.

Ponanperuma - Gabel 1968 Ponnamperuma, Cyril - Gabel, Norman W.: Current status of chemical studies on the origin of life. Space Life Sciences 1. 64-96.

Sato - Tatsumo - Matsuo 1970 Sato, Motomu - Tatsuno, Takashi - Matsuo, Hisayuki: Studies on the racemization of amino acids and their derivatives. IV. Structural relation of amino acids to their racemizability in acetic acid. Yakugaku Zasshi 90/9. 1160-1163.

Schroeder - BadA 1973 Schroeder, Roy A. - Bada, Jeffrey L.: Amino acid racemization and their geochemical implications. Science 182. 479-487.

SMITH - PANICO 1985 Smith, Robert J. - Panico, K. A.: Automated analysis of o-phthalaldehyde derivatives of amino acids in physiological fluids by reversed phase high performance liquid chromatography. Journal Liquid Chromatography 8. 1783-1795.

Smith et AL. 1976 Smith, Grant Gill - Williams, K. M. - Astill, D. M. - Sivakna, T. - Vonacott, D. M.: Paper 226. Presented by the $172^{\text {nd }}$ ACS National Meeting. San Francisco, California, 1976.

Smith - Khatib - Sudhakar Reddy 1983 Smith, Grant Gill - Khatib, Avni - Sudhakar Reddy, G.:The effect of nickel(II) and cobalt(III) and other metal ions on the racemization of free and bound L-alanine. Journal of American Chemistry Society 105/2. 293-295

SMITH - RedDy 1989 Smith, Grant Gill - Reddy, Vanita G.: Effect of the side-chain on the racemization of amino-acids in aqueous-solution. Journal of Organic Chemistry 54. 4529-4535.

StePhen-Sherwood - Oro 1973 Stephen-Sherwood, E. - Oró, Joan: Chemical evolution, recent syntheses of bioorganic molecules. Space Life Sciences 4. 5-31.

TeRENTEV - KLABUnOVSKII 1957 Terentev, A. P. - Klabunovskii, E. I. 1957. In: Oparin, A. I. (ed.): First International Symposium on the Origin of Life on Earth. New York, 1959.

TAPUHI ET AL. 1981 Tapuhi, Yitzhak - Schmidt, Donald E. - Lindner, Wolfgang - Karger, Barry L.: Dansylation of amino acids for high-performance liquid chromatography analysis. Analytical Biochemistry 115. 123-129. 
VAlLENTYNE 1964 Vallentyne, John R.: Biogeochemistry of organic matter. 2. Thermal reaction kinetics and transformation products of amino acids compounds. Geochimica et Cosmochimica Acta 28/2. 157-188.

VANT Hoff, I. 1908 In: Die Lagerung der Atome in Raune, Vierweg. Braunschweig, 1908.

Wehmiller - Hare 1971 Wehmiller, John F. - Hare, Peter E.: Racemization of amino acids in marine sediments. Science 173. 907-914.

Wehmiller - Hare - Kujala 1976 Wehmiller, John F. - Hare, Peter E. - Kujala, G. A.: Interlaboratory comparison of amino acid enantiomeric ratios in fossil Pleistocene mollusks. Geochimica et Cosmochimica Acta 40. 763-769.

WEINSTEIN - WEINER 1984 Weinstein, Shlomo - Weiner, Stephen: Enantiomeric analysis of a mixture of the common protein amino acids and their Dns derivatives. Journal of Chromatography 303. 244-250.

WiLLIAMs - SMIтH 1977 Williams, K. M. - Smith, Grant Gill: A critical evaluation of the application of amino acid racemization to geochronology and geothermometry. Origins of Life 8. 91-144.

WILTSHIRE 1953 Wiltshire, G. H.:The estimation of d- and l-glutamic acid in proteins. Biochemical Journal 55. 46-49.

WoodWARD - GILMAn - Engelhart 1990 Woodward, Cliff - Gilman, L. B. - Engelhart, Gary W.: An evaluation of microwave heating for the vapor phase hydrolysis of proteins. Int. Laboratory 1990. 40-46. 
